\title{
„Magyar", illetve „török" arany- és ezüstfonalak 17. századi magyar hímzéseken? A korszak „,fémfonal-palettája” az írott források és az archeometriai elemzések tükrében ${ }^{1}$
}

\author{
1JÁRÓ MÁRTA
}

${ }^{1} \mathrm{H}-1143$ Budapest, Jurisich Miklós u. 9., e-mail: jaro.mart@gmail.com

JÁRÓ, M.: "Hungarian" and "Turkish" gold and silver threads - were they used in $17^{\text {th }}$ century Hungarian embroideries? The "palette of metal threads" of the period according to the contemporary written sources and the archaeometrical examination Abstract: A comparison of the assortment of metal threads mentioned in different documents with the results of the scientific investigations of samples is given in the study, aiming to discover the meaning of the denotations "Hungarian" and "Turkish" in connection with gold and silver threads of the period.

Keywords: metal thread, gold thread, silver thread, embroidery, study of written sources, scientific investigation

„Háló fökötők Nro.10. Ki török, ki magyar arannyal varrott, ki csipkés." Thököly Mária 1643-ban kelt hozományjegyzékéből²

„Két fél ümög egyik magyar ezüsttel a másik török arannyal ezüsttel vagyon varrva." Viczay Mária ingó marháinak 1656-os összeírásából ${ }^{3}$

\section{Bevezetés}

A hódoltság kori, három részre szakadt Magyarország területén tovább élt az igény az egyházi és világi öltözetek, valamint a liturgikus terekben, illetve a háztartásokban használatos textíliák hímzéssel való díszítésére. A jellegzetesen magyarnak mondható, az ország területén elterjedt, keleti (föként oszmán-török) és nyugati hatásokat ötvöző mintákat nem csak a főúri, hanem a kevésbé gazdag porták asszonyai is szívesen varrták vagy varratták ruháikra, keszkenőikre, a templomoknak készített terítőkre és más textíliákra (1. és 3. ábra).

A főként növényi motívumok, levelek, virágok hímzésénél, más anyagok, elsősorban a selyem mellett sokszor alkalmazták az arany- és ezüstfonalakat is. Némely 17. századi lajstromkészítő ez utóbbiak közül egyeseket "magyar", illetve "török" jelzővel látott el, ${ }^{4}$ ahogyan ezt például Thököly Mária főkötőinek vagy Viczay Mária ingjeinek számbavevője tette (Id. a fent említett tételeket). Palotay Gertrúd, aki sokat foglalkozott e törökös jelleggel is bíró magyar hímzésekkel, arra a megállapításra jutott, hogy: „Ma már nem tudjuk, miben rejlett a «magyar arany» és a «török arany» közti különbség." Ugyanő egy másik helyen megjegyzi: „A különbség mindenesetre nem vonatkozhatott a nemes fém minőségére, mert hiszen a leltározók nem vették a lajstromozandó textilholmit olyan beható vizsgálat alá, mely a nemes fémfonal tulajdonságait kideríthette volna." Ezt a hiányt szerettük volna pótolni, amikor elkezdtük a 16-17. századi, magyarként számon tartott hímzések fémfonalainak vizsgálatát.

1 E cikkel szeretném köszönteni régi „harcostársamat”, Költő Lászlót, akivel sok közös archeometriai feladatunk volt, és aki „archeométerként" mindig segítette munkámat.

2 RAdVÁNSZKY II. 1879, 285.

3 RadvánszKY II. 1879, 326.

4 Néhai László Emőke múvészettörténész hívta fel évtizedekkel ezelőtt a figyelmemet a „magyar arany - török arany” problémakörre, és ösztönzött arra, hogy a fémfonal-kutatások során e témával is foglalkozzam. Ezúton is köszönöm ezt neki és tisztelgek emlékének! Ő, aki Odafönn már bizonyára tudja a helyes választ, remélem, elnézi nekem, ha az enyém korrekcióra szorul!

5 PaLotay 1940, 17-18. Palotayra hivatkozva Agnes Geijer is írt a két fonalfajtáról, de nem tért ki arra, hogy miben különbözhetnek egymástól, illetve a többi arany-, illetve ezüstfonaltól. (GeJer 1951, 66.) A korszak hímzései kapcsán Veronika Gervers is megemlítette ezeket (Gervers 1982, 6.), ahogyan László Emőke is (LÁszLó 2001, 7.). Néhai Újszászy Kálmánné, Palágyi Deák llona, a Sárospataki Református Kollégium Tudományos Gyűjteményeinek Múzeuma igazgatója szintén foglalkozott e problémakörrel, de nincs tudomásom arról, hogy kutatási eredményeit publikálta volna. 
A fémfonal kifejezést a továbbiakban, általános értelemben, a tömör ${ }^{6}$ fémből/fémekből készült, szál jellegú díszítményekre alkalmazzuk. Konkrétan a fonal szó vezetőfonalra, az ún. bélfonalra (selyem, len stb.) font fémszalagot vagy drótot jelöli. ${ }^{8}$ Összetett fonalak esetében számos további variáció létezik. ${ }^{9} \mathrm{~A}$ sodrat a bélfonalra fonás/sodrás irányát adja meg: balról jobbra ( $\mathrm{S}$ sodrat) vagy fordítva (Z sodrat).

Könnyủ dolgunk lett volna, ha találunk olyan hímzéseket, amelyekről fennmaradt egykorú leírás (leltárban, számlán stb.) „magyar arany” vagy „török arany”megjelölésekkel. A mütárgyak elemzése és a hímzőfonalak természettudományos analízise együttesen talán egzakt választ tudtak volna adni a címben szereplő kérdésre, vagy legalábbis közelebb vittek volna a megoldáshoz. Sajnálatos módon azonban nem volt ekkora szerencsénk. Így azután a kutatás két szálon futott. Megkíséreltük egyrészt áttekinteni a rendelkezésünkre áló, egykorú források vonatkozó adatait: milyen fémfonalak jelentek meg a hímzéseken az adott korszakban, hol és mikor használták ezekkel kapcsolatosan a "magyar", illetve "török" jelzőket. Vizsgáltuk, hogy honnan szerezhették be az árut, említenek-e az ország területén tevékenykedő, ezek készítésével foglalkozó mestereket, műhelyeket, céheket. ${ }^{10} \mathrm{Az}$ átnézett dokumentumok elsősorban a fejedelmi udvarokhoz, nemesi vagy gazdagabb polgári portákhoz kötődnek, így nem adnak képet - a fémfonalak területén sem - a szegényebb rétegek által használt, vagy azok háztartásában megjelenő tárgyi anyagról.

A kutatott korszak szoros értelemben véve a 17. század volt, mivel az előzetes tájékozódás során az 1600-as évek irataiban találkoztunk a "magyar" és „török" jelzőkkel, fémfonalakkal kapcsolatosan. Vizsgálódásaink során azonban a 16. század második felének, illetve a 18. század első évtizedeinek dokumentumait is megpróbáltuk nagy vonalakban áttekinteni, ugyanis a fémfonalas textíliákat - nagy értéküknél fogva - több generáción át viselték, örizték. Egy-egy fonalfajtával esetenként évtizedekig, sőt talán hosszabb ideig is hímeztek, sokszor együtt használva azokat újabb, modernebb változataikkal. A leltárakban pedig akár egy-két motringot, fel nem használt aranyfonalat is külön tételként szerepeltettek. ${ }^{11} \mathrm{~A}$ forráskutatással párhuzamosan 17. századi magyar hímzésekről vett fémfonal-minták morfológiai- és anyagvizsgálatát végeztük el annak megállapítására, hogy az arany-, illetve ezüstszínú fonalak csoportjában vannak-e, és ha igen, milyen jellegú különbségek és utalhatnak-e ezek az eredetre. A kapott eredményeket összehasonlítottuk nem magyar hímzésekröl, illetve szövetekről származó, 16-17. századi fémfonalak elemzési eredményével. Végezetül a kapott adatokat összesítve próbáltuk megválaszolni a címben feltett kérdést.

\section{A hímzések arany- és ezüstfonalai az egykorú dokumentumok tükrében}

A forráskutatás során a legtöbb információt a vásárlási listák, árszabások, vámjegyzékek valamint a különböző összeírások (hozományjegyzékek, végrendeletek, hagyatéki- és egyéb leltárak stb.) adtak, de más iratokban, magánlevelekben is többször utaltak különböző fémfonalakra, azokkal készült textíliákra. A dokumentumok többségét a 19. században közölték, de sok hasznos adatot találtunk később kiadott publikációkban is.

\section{Utalások a fémfonalak morfológiájára 17. századi dokumentumokban}

Morfológiai, azaz alaktani szempontból az egykorú, gazdasági jellegủ iratokban font/fonott (aranyat/ezüstöt), (arany- és ezüst) fonalat, vont (aranyat/ezüstöt), illetve skófiumot, ritkán klabodánt valamint lapos- vagy vert (aranyat) különböztettek meg. Az elnevezések, úgy tűnik, többé-kevésbé általánosak voltak, a lajstromozók is főként ezeket használták.

Thurzó llona kézfogójára például 1614-ben fonott aranyat és ezüstöt, illetve vont ezüstöt vásároltak. ${ }^{12}$ Klabodánt említenek - többek között -, egy már elkészült hímzéssel kapcsolatosan Bethlen Gábor fejedelem számadáskönyvében 1622-ben. ${ }^{13} \mathrm{~A}$ font arany/ezüst, az arany/ezüstfonal valamint a klabodán ${ }^{14}$ nagy valószínúséggel a bélfonalra font fémszalagra vonatkozik (2. ábra a). Talán erre a fémfonal-fajtára gondolhatott a Vér György ingóságairól 1697-ben leltárt készítő is, amikor motringos arannyal varrott lepedőt említett. ${ }^{15} \mathrm{~A}$ vont arany/ezüst, ha áruként, leltározandó tételként szerepel, vékony, hímzéshez használható drótot, skófiumot je-

6 A „tömör" jelzővel különböztetjük meg a csak fémből készült szalagokat az ún. kombináltaktól, amelyeket fémmel borított szerves anyagból (bőr, papír stb.) vágtak. Az utóbbiakkal a vizsgált anyagban nem találkoztunk.

7 Ld. pl. az 2. ábrán négy változatukat (a-d)

8 Ld. pl. az 2. ábrán a és d.

9 Ld. pl. Járó 2010b, 58-59.

10 A munka egy akadémiai pályázat keretében kezdődött a kilencvenes évek végén. Az azóta eltelt időszakban további forráselemzésekre és anyagvizsgálatokra került sor.

11 Ld. pl. Hathalmy Péter ingóságai 1563-as jegyzékében: „Keth mothrigh Araÿan fonal.” DöBRENTEl 1842, 49.

12 Három, egymás alatt szereplő tétel (árral): „2 uncz fonott ezüst...", „3 cheff [=cséve] vont ezüst...", „2 uncz fonott-arany...", RAdVÁnszky II. $1879,200$.

13 „Az varró mívek elkészülvén, ment reájok skófium arany, ezüst és klabodan...”, RAdVÁnszky 1888, 56., vö. PÁszTOR 1997, 37.

14 A klabodán a klaptan török elnevezés „magyarított” változatának tünik. Vö. PÁszToR 1997, 14. lj.

15 „Edgy gyolcs lepedö, a két végi zöld selyemmel és motringos aranynyal varrott." KомÁromr 1885, 2, 406. 


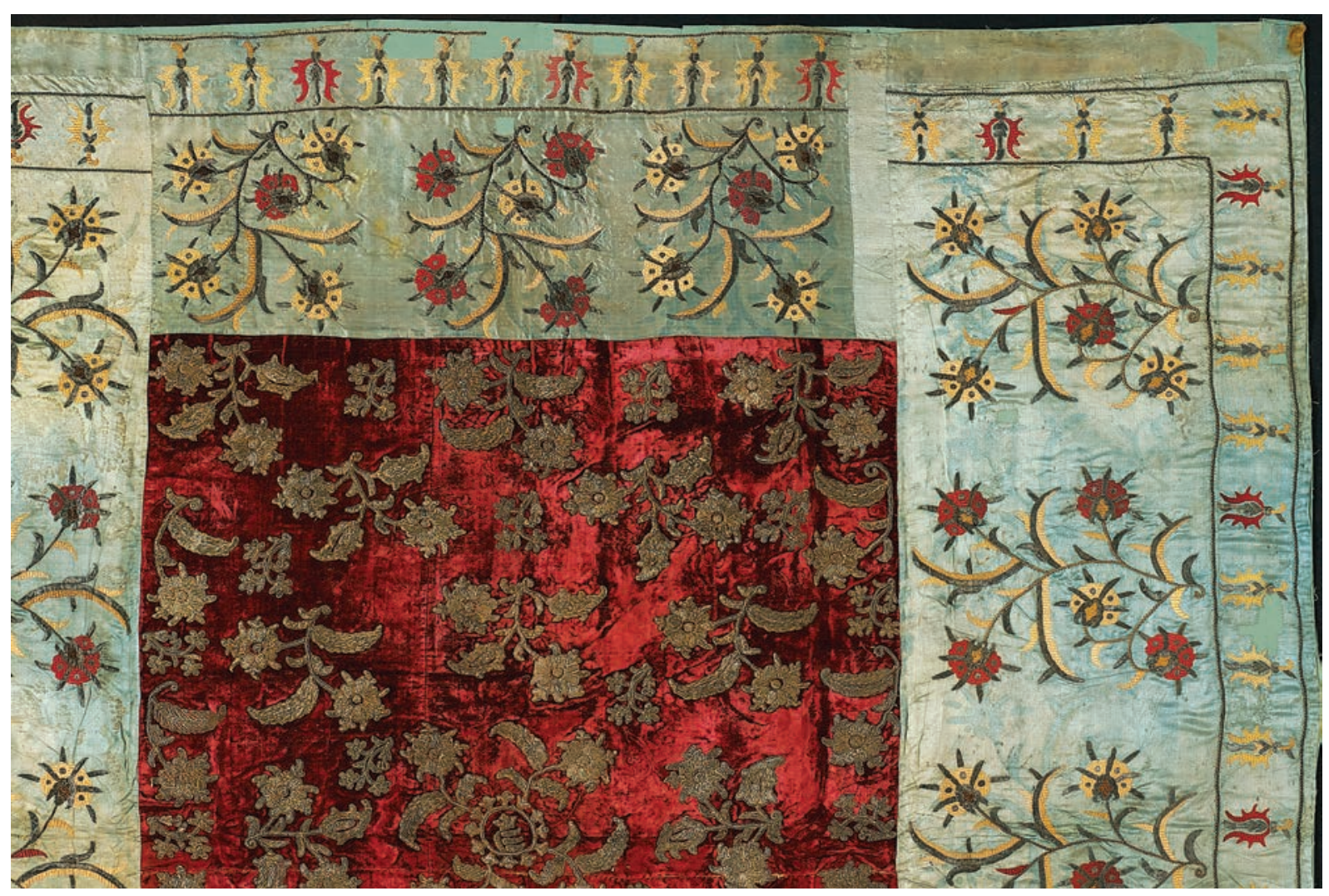

1. ábra. Báthory-címeres ágyterítö, Erdély, 17. század első negyede, részlet Iparmüvészeti Múzeum, Itsz.: 52.1384.1 (Áment Gellért felvétele)
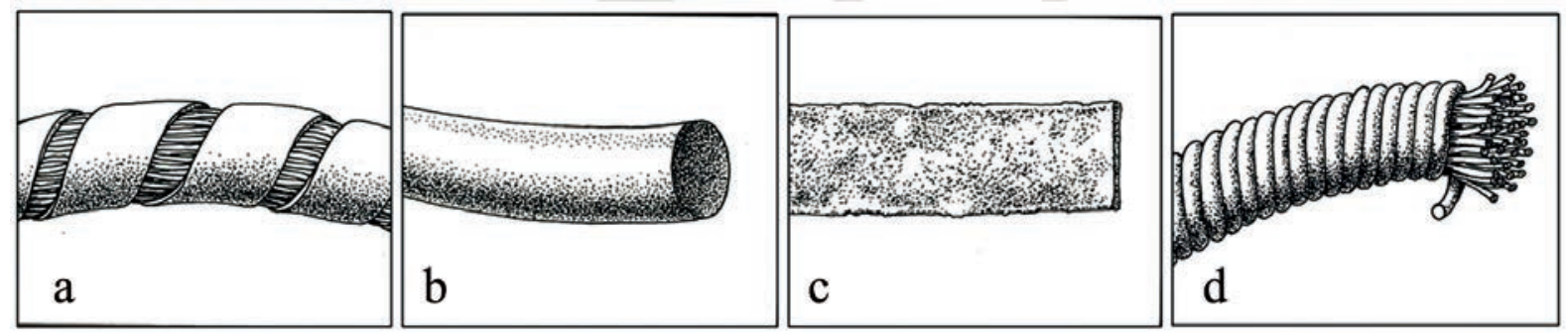

2. ábra. A leltározók által morfológiájuk alapján megkülönböztetett fémfonalak: a. font/fonott (arany/ezüst), (arany/ezüst)fonal, klabodán, esetleg motringos (arany); b. drót/skófium vagy vont (arany/ezüst); c. lapos- vagy vert (arany); d. skófium (arany)fonal, tekert skófium(?)

Iöl (2. ábra b). ${ }^{16}$ Amennyiben a vont arany/ezüst kifejezés ruhadarabbal vagy valamilyen késztermékkel kapcsolatban jelenik meg (szövet, díszítőszalag, rojt, csipke stb.), akkor valószínüleg általánosságban fémfonallal készült méterárura utal. ${ }^{17}$ Károlyi Judith ingóságai között 1666-ban egy lapos arannyal hímzett "elöruha", ${ }_{11}^{18}$ míg a Thököly javak egy 1684 körüli összeírásában vert-arannyal és -ezüsttel varrott vánkos(héj?) ${ }^{19}$ szerepel. A laposvagy vert arany/ezüst talán a bélfonal nélküli, drótból hengerelt, arany-, illetve ezüstszínű szalagot (lamella) jelentheti (2. ábra c). Skófium aranyfonalat vett Keresztesi Pál Konstantinápolyban Bethlen Gábor fejedelem részére 1625 -ben. ${ }^{20}$ Ez vélhetően a bélfonalra sodort drótot jelenti (2. ábra d), mivel a beszerző a vásárlási lista ugyanazon oldalán skófiumot is említ. Károlyi Ádám 1661-es hagyatéki leltárában az összeíró tekert skófium-

16 Ld. pl. a 13. lábjegyzetben. A skófium szó eredetére vonatkozóan eddig nem találtunk adatot.

17 Ld. pl. a Bethlen Gábor fejedelem udvarában vezetett, 1615-ös számadáskönyvben: [vettem] „24 réf virágos vont ezüstöt...” [azaz 24 röf ezüstfonallal vagy -dróttal szőtt, virágmintás szövetet]. RADVÁNsZkY 1888, 5.

18 GÉRESI 1887, 461.

19 Thaly 1873, 697.

20 RADVÁNSZKY 1888, 117. 
ról, ${ }^{21}$ az 1611 áprilisában vámjegyzéket készítő Kolozsváron tekert rézrő|l22 ír talán ugyanerre a fonaltípusra utalva, bár ezekben az esetben nem kizárható a két vagy több drót összesodrásával készült fémfonal sem.

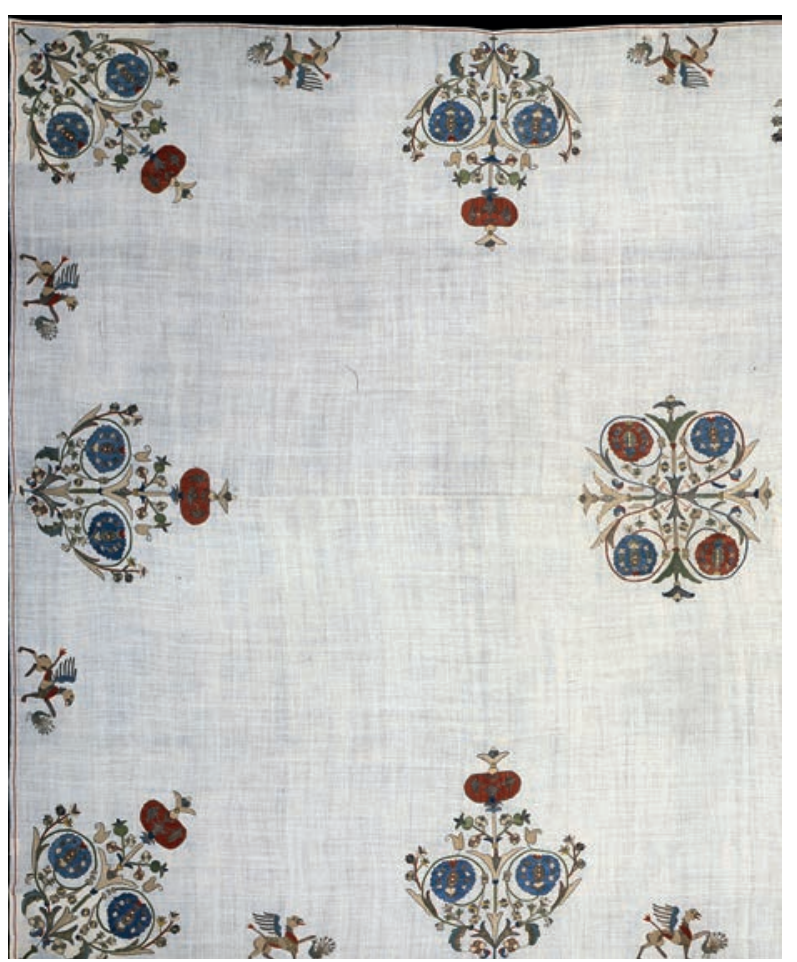

3. ábra. Úrasztali terítő, Észak-Magyarország, 17. század közepe, részlet, Iparmüvészeti Múzeum, Itsz.: 19.461 (Kolozs Ágnes felvétele)

\section{A fémfonalak anyaga a 17. századi dokumentu- mok alapján}

Az egykorú iratokban főként aranyról, ezüströl, ritkán aranyozott ezüstről és rézről esik szó.

Az arany használatát szinte minden átnézett, fémfonallal valamilyen módon kapcsolatos dokumentumban említik. Arany és arany között csak ritkán tesznek különbséget, ha igen, akkor ez feltehetően látványbeli eltérésre utalhat. Fényes arannyal varrt lepedők szerepelnek például Andrássy Mátyásné Monoki Anna 1651-es végrendeletében, fehér fényes aranynyal hímzett ingváll Barchay Judith asszony "portikái” között 1666-ban. ${ }^{23}$ Síkos arannyal készült egy fökötő, amelyet Balpataki Jánosné árváinak javai között írnak le 1652-ben. ${ }^{24}$ Lyoni aranyat használtak egy ágytakaró hímzett rózsáinak díszítéséhez a csáktornyai várban 1671-ben összeírást készítő szerint. ${ }^{25}$ Magyar arannyal varrott nyári kesztyűt említ a lajstromozó az 1642-es Esterházy leltárban. ${ }^{26}$ Török arannyal (és -ezüsttel) hímeztek Thököly Mária hozományul kapott ingvállai közül kilencet az 1643 -as jegyzék szerint. ${ }^{27}$ Aranyskófium vásárlásáról a legkorábbi adatot az 1616. évi, márciusi kolozsvári harmincadjegyzékben találtuk. ${ }^{28}$ A skófiumokat esetenként színük szerint különböztetik meg, például fehér és sárga skófiummal szőtt száras gomb szerepel „Nagyságos Alia Maria Kis Aszszonynak" javai között 1648-ban. ${ }^{29}$ Ugyanígy találunk szín szerint megkülönböztetett klabodánt is, például sárga klabodánt vettek Bethlen Gábor fejedelem számára 1625 -ben. ${ }^{30}$

Aranyozott ezüstről viszonylag ritkán írnak, de például említik egy női köpeny kapcsán, amelyet aranyozott ezüst- és aranyrojtokkal szegélyeztek a korábban idézettől némiképp eltérő, de azzal egykorú, 1671-es csáktornyai leltárban, ${ }^{31}$ és valószínűleg az esetenként használt aranyas ezüst kifejezés is erre utal. ${ }^{32}$

Az ezüstfonal, illetve ezüstskófium rendszerint az arannyal együtt, de esetenként „önállóan” is előfordul. Egyes leltározók ezüst és ezüst között is tesznek különbséget, ahogy ezt az aranynál is láttuk. Egy magyar- és egy török ezüsttel (és arannyal) varrott "fél ümög" szerepel például Viczay Mária ingóságainak 1656-os összeírásában. ${ }^{33}$ További ezüstfajta, a lyoni ezüstfonal jelenik meg az 1671-es, hosszabb csáktornyai leltárban. ${ }^{34}$ Hamis ezüst csipkével díszített függönyöket említenek az óvári kastély ingóságai között 1661-ben. ${ }^{35}$

21 „Egy türkeses ezüstös aranyas nyereg,... tekert skófiommal környül varrva..." GÉRESı 1887, 419.

22 PAP 2000, 158.

23 RAdVÁNSZKY III. 1879, 323, illetve BARANYAI - CSERNYÁNSZKY 1984, (fasc. 118/5) 306.

24 Baranyal - CSERnYÁnszky 1981, (fasc. 89/13) 146.

25 "Item tegumentum... in medio flava taffotta cum rosés acu pictis, leonici auri intermixtis..." CSERNYÁNSZKY 1990, (fasc. 101/26) 30. (hoszszabb leltár)

26 „Ittem egi Niari kesztiw attlaczra varrott magiar arannial”, ESTERHÁZY INVENTARIUM 1642, 6.

27 "Ingváll Nro 50. Ezek között törők arannyal, ezüsttel varrott Nro 9.", RADvÁnszky II. 1879, 285.

28 „Bogar Janos vizen Magiarorzagban 6 Leuel zgofium araniat..." PAPp 2000, 245.

29 BARANYAI - CSERNYÁNSZKY 1984, (fasc. 111/3) 149.

30 [vettem] „...papíros skófium aranyat sárga klabodánnal együtt...”, RADVÁNszky 1888, 119.

31 "Chlamys alia ex bisso muliebris cum subductura sobolina, et fimbriis argenteis deauratis, et aureis circumdata", CSERNYÁNSZKY 1990, (fasc. 101/26) 26. (rövidebb leltár)

32 „....Aranyes Ezwst fonalas Mayczu Lora valo szerrszam”, BARANYAI - Csernyánszky 1984, (fasc. 118/2) 137, de előfordul más vonatkozásban is, pl. „Két aranyas ezüst kanna”, SzILÁGYI 1887, 210.

33 Ld. a cím alatt szereplő második idézetet és a 3. lábjegyzetet.

34 „...ex filo leonico argento...", CSERnYÁnsZKY 1990, (fasc. 101/26) 32. (hosszabb leltár)

35 „...az másik superlat..., a kin hamis ezüst csipke vagyon...” RADVÁNSZKY II. 1879, 346. 
Rézzel, mint fémfonal alapanyaggal inkább csak a kolozsvári harmincadjegyzékekben találkoztunk, például 1602-ben rézfonalat vámoltak. ${ }^{36}$

Nagy valószínűséggel a fémfonal anyagára utal a sík megjelölés is. Fényes síkkal hímzett lepedő szerepel például Bethlen Farkasné ingóságainak 1679-es lajstromában, ${ }^{37}$ és vont sík fonalat szereztek be Krakkóban Bethlen Gábor fejedelem udvartartása számára 1622-ben.38

A leírások nem egyazon „protokoll” szerint készültek (ahogy napjainkban sem...), és a lajstromozók nem használtak egységes terminológiát (ahogy ma sem...). Előfordult, hogy ugyanazon személy egy-egy listán belül, feltehetően ugyanarra a fémfonal-fajtára más-más elnevezést használt, vagy más-más személy ugyanazt a darabot különböző módon írta le. A dokumentumok pontossága az összeíró ismereteitől, alaposságától, a leírt darabok állapotától (például új darabok hozományjegyzékekben vagy korábban készültek, amelyeken már korrodálódott a fém, például végrendeletekben), de a dokumentum „fontosságától” is függött.

\section{A forrásokban említett arany- és ezüstfonalak az archeometriai vizsgálatok tükrében}

Az alábbiakban több, mint negyven, 17. századra datált, magyar hímzésről (egyházi- és világi öltözetek, terítők, ágytakarók, párna- és lepedőszélek, keszkenők stb.) származó, több, mint hetven, egyszerű morfológiájú, arany- és ezüstszínú fémfonal vizsgálati eredményeit foglaljuk össze. ${ }^{39} \mathrm{~A}$ tárgyak többségénél a minták nem reprezentálják az egész hímzést, ugyanis sok esetben többféle, alaktanilag és/vagy anyagában eltérő fonalat használtak ugyanazon darabon.

Az egyes minták alaktani hovatartozását, jellemző méretét/méreteit, a bélfonal színét, szerkezetét (anyaga azonosításához) stb. optikai mikroszkóp segítségével ráeső, illetve áteső fényben tanulmányoztuk. A felület mikromorfológiáját, az esetlegesen még megfigyelhető szerszámnyomokat pásztázó elektronmikroszkóppal (SEM) vizsgáltuk.

A fémfonalak készítéséhez használt fémszalagok, illetve drótok anyagának minőségi és félmennyiségi elemzése energiadiszperzív mikroanalízissel (SEM-EDS) történt ${ }^{40}$ a fémfelszín egy-egy "nagyobb”, akár 0,10$0,15 \mathrm{~mm}^{2}$ területén, ${ }^{41}$ fonalnál a bélfonalról letekert, kisimított szalag külső és belső oldalán egyaránt. Kiegészítésként, több esetben, a keresztmetszeten is végeztünk méréseket. Így próbáltuk csökkenteni a felszín és az alatta lévő rétegek inhomogenitásából adódó hibákat. ${ }^{42}$

Korábban már több publikációban ismertettük az egyes fémfonal-fajták készítéstechnikájának rekonstruálására tett kísérleteinket. Mivel a vizsgálatok idehaza és világszerte folytatódtak-folytatódnak, az alábbiakban ezek eredményeivel kiegészítve próbáljuk összegezni jelen ismereteinket/feltételezéseinket a kutatott anyag kapcsán.

A morfológiai elemzések során a forrásokban említett, egyszerű fémfonal-változatok szinte mindegyikét lehetett azonosítani. A mikroszkópos vizsgálatokkal csak finomítani tudtuk a leltárkészítők, számadásokat összeállítók megállapításait. A müszeres analízis eredményei alapján viszont árnyaltabbá vált a kép.

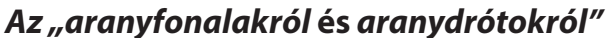

Az aranyból, illetve aranyötvözetből készült, föként hímzéshez, illetve keskeny díszítőszalagok szövéséhez használt fonalak és drótok, az eddigi külföldi és hazai elemzések adatai alapján, a 14. századtól „eltűntek" az európai „fonalpiacokról". Helyettük szintén tömör, aranyozott ezüstszalagok felhasználásával készült fonalakat, illetve vékony, aranyozott ezüstdrótokat használtak. Kérdés, hogy a 17. századi leltározók többsége ennek tudatában említ-e aranyfonalat vagy aranyskófiumot. Mindenesetre például, a már idézett, rövidebb, 1671es csáktornyai összeírás készítője megkülönbözteti az aranyozott ezüstöt az aranyfonaltól. ${ }^{43}$ Az 1704-ben a

36 Ld. pl. PAP 2000, 125. vagy fentebb a 22. lábjegyzetet.

37 Patyolat lepedő, fényes síkkal és magyar arannyal írás után varrva" LUKINICH 1908, 15.

38 [vettem] „3/4 [lat] vont sík fonalat...", RADVÁNsZKY 1888, 66.

39 A negyvenkét hímzés többsége három múzeumi gyűjtemény (nem ásatásból származó) műtárgyai közé tartozik. Ezúton is köszönöm dr. Pásztor Emese főosztályvezetőnek (Iparművészeti Múzeum, Textil- és Viseletgyűjtemény), dr. Tompos Lilla művészettörténésznek (a Magyar Nemzeti Múzeum Textilgyűjteményének korábbi vezetője) és Pocsainé dr. Eperjesi Eszter múzeumvezetőnek (Sárospataki Református Kollégium Tudományos Gyűjteményeinek Múzeuma), hogy lehetővé tették a mintavételt és elláttak tanácsaikkal. Köszönettel tartozom a gyűjteményekben tevékenykedő kollégáknak is, akik segítségemre voltak a mintagyűjtésnél, és megosztották velem az egyes textíliákkal kapcsolatos megfigyeléseiket.

40 A SEM-EDS vizsgálatok során a minta felületének gerjesztése (egyes korai elemzéseket leszámítva) 25 kV energiájú elektronsugárral történt, hogy növeljük a behatolási mélységet, és így a rétegszerkezetről is kapjunk tájékoztató információt. A kapott (100\%-ra normált) tömegszázalékos értékek tájékoztató jellegűek. A SEM felvételekért, illetve a SEM-EDS elemzésekért köszönet illeti dr. GálSólymos Kamilla vegyészt (ELTE TTK, Ásványtani Tanszék) és dr. Tóth Attila fizikust (MTA Műszaki, Fizikai és Anyagtudományi Kutató Intézet). A vizsgálati eredmények egy részét Id. JÁRó 2010a, 289-298. (1. és 2. táblázat), valamint az egyes textíliák technikai leírásában, in: EsterhÁZY GYüJTEMÉNYI SZAKKATAlóGUS II. 2010. Az eredmények másik része publikálatlan.

41 Természetesen ez a terület csak a mikroanalíziseknél számít "nagynak".

42 A problémákról Id. pl. Costa - De Reyer - Betbeder 2012, 112-115; Weiszburg et Al. 2017, 10753-10754.

43 Ld. a 31. lábjegyzetet 


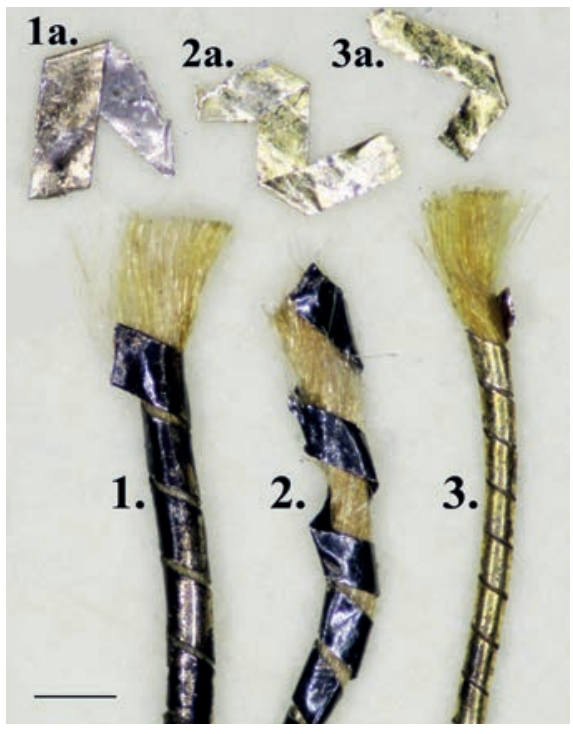

4. ábra. Különböző mértékben korrodálódott aranyozott ezüstfonalak és a felhasznált fémszalagok egy-egy letisztított darabja. Optikai mikroszkópos felvétel, marker $0,5 \mathrm{~mm}$

- 1. Erősen korrodálódott fonal. Magyar hímzés, 17. század második fele. Tisztítás után a szalag kívül arany-, belül ezüstszínü (1a). Egy oldalon aranyozott ezüstszalag sárga selyemfonalra fonva, S sodratban.

- 2. A 3. ábrán látható terítő hímzőfonala. Tisztítás után a szalag kívül-belül aranyszínü (2a). Két oldalon aranyozott ezüstszalag sárga selyemfonalra fonva, $S$ sodratban.

- 3. Kevéssé korrodálódott (takart részről származó) fonal. Itáliai hímzés, 17. század eleje. Tisztítás után a szalag kívülbelül aranyszínü (3a). Két oldalon aranyozott ezüstszalag sárga selyemfonalra fonva, S sodratban. görgényi várban lajstromozó négy török lótakaróról azt írja, hogy közülük hármat aranyfonallal (ezen feltehetően aranyozott ezüstöt ért), egyet pedig igazi arany- és ezüstfonallal díszítettek. ${ }^{44}$ Több más dokumentumban is találkoztunk aranyozott ezüst- és aranyfonallal ugyanazon leltárban, amiből arra következtethetünk, hogy talán nem mindenki volt ezzel tisztában. A kereskedők és a vámjegyzékek összeállítói viszont bizonyosan igen, hiszen az „arany”- és az ezüstfonal, illetve a kétféle skófium súlya és ára akkoriban (már) alig különbözött egymástól. ${ }^{45}$

\section{Aranyozott ezüst- és ezüstfonalak}

$\mathrm{Az}$ aranyozott ezüstfonalak mindkét ismert változatát lehetett azonosítani a hímzéseken: az egyik esetben az aranyréteg csak az ezüstszalag külső oldalát fedi (a továbbiakban „egy oldalon aranyozott ezüstfonal"), míg a másik esetben a külső és belső oldalát egyaránt („két oldalon aranyozott ezüstfonal”) (Id. pl. 4. ábra 1a, illetve $2 a$ és $3 a$ ). Eredetileg mindkettő a finomított aranynál talán "sápadtabbnak", de aranynak látszott. ${ }^{46}$ Az idő múlásával azonban a felületük, az aranyétól eltérően, elvesztette fényét (4. ábra 3), majd megsötétedett a kialakuló korróziós termékréteg (főként az ezüst korróziós termékei) miatt (4. ábra 1. és 2.).

Az egy oldalon aranyozott ezüstfonal, eddigi ismereteink szerint, valamikor az első ezredforduló tájékán tűnt fel Európában, és kezdetben párhuzamosan használták az aranyból, illetve aranyötvözetből készültekkel. ${ }^{47}$ A 14. századtól azután, körülbelül a 16. század közepéig-végéig „egyeduralkodónak” tekinthető az Európában készült, tömör, aranyszínű fonalak között. Az átlagosan kb. 0,2-0,4 milliméter széles szalagokat, minden valószínűség szerint vékonyra (kb. 0,02-0,03 milliméter) kalapált, egyik oldalán aranyozott ezüstlemezből vagy szélesebb szalagból vágták. ${ }^{48} \mathrm{~A}$ csoporton belül, az alapfém összetétele alapján két alcsoportot lehetett eddig elkülöníteni: a rezet nem, vagy csak kis mennyiségben tartalmazó ezüstökét (a mért rézkoncentráció $2 \%$ alatt volt), ${ }^{49}$ illetve az ezen értéknél magasabb réztartalmúakét. ${ }^{50} \mathrm{Az}$ utóbbi esetben az ezüstöt nem tudták vagy szándékosan nem akarták kb. 980 \%o-nél magasabb értékig finomítani. Ennek okáról megoszlanak a vélemények. ${ }^{51} \mathrm{~A}$ kis réztartalmú ezüst aranyozása valószínűleg segédanyag (forrasztóanyag) nélkül aranyfóliával vagy esetleg tűziaranyozással (aranyamalgámmal vagy higannyal és aranyfüsttel) történhetett, mindkét esetben hő segítségével, az aranyozott ezüst vékonyítása előtt. A magasabb réztartalmúaknál a Theophilus presbiter által a 12 .

44 Dorsualia Turcica quatour, quorum tria auro filato, unum vero aureo et argenteo filo... ornata" JAKAB 1875, 174.

45 Ld. pl. „...le fil d'argent couste quasi autant que le fil d'or.” [..az ezüstfonal körülbelül annyiba kerül mint az aranyfonal] (BıNEt 1622, 213.) vagy az 1627-es, Bethlen-féle árszabásban: „Szkofium arannak egész papirossát, ki negyedfél lót, adják öt forinton”, majd alatta a listán: „Az ezüstnek papirossát négy forinton hetvenöt pénzen”, ERDÉLYI ORSZÁGGYüLÉSI EMLÉKEK 1882, 384. (Feltételezve, hogy ugyanolyan hosszúságú fonalról volt szó.)

46 Az aranyozott ezüstszalagok letisztításával természetesen nem tudjuk megjeleníteni (visszaállítani) azok eredeti színét, állapotát.

47 Theophilus presbiter pl. ezt írta a 12. század elején: „llyenből [az egy oldalon aranyozott ezüstszalagokról van szó] szövik a szegények számára az aurifrigiumokat ugyanolyan módon, ahogyan a gazdagok számára, csak az utóbbiaknak tiszta aranyból.", TAKÁcs $1986,127$. Egyidejű alkalmazásukat a korai anyagon végzett analitikai vizsgálatok eredményei is igazolták (Id. pl. JÁRó 2004, 311-313.).

48 Az egy oldalon aranyozott ezüstszalagokról bővebben ld. pl. JÁró 2003, 27-45.

49 A vizsgálati eredmények alapján választott határérték, amely összecseng, pl. egy 1586-os francia, királyi rendelet vonatkozó részével. Ennek értelmében a fémfonal-készítők csak a pénzverők valamint az ötvösök által használtnál finomabb ezüstöt, színezüstöt (12 deniers, azaz 1000\%o) dolgozhattak fel. Az engedélyezett, csekély eltérés (4, illetve 6 grains) kb. 15\%o, majd később (1657-től, Lyonban) 21\%o volt. Vagyis maximum kb. 2\% ötvözőt tartalmazhatott az ezüst. Vö. BoızARD 1692, 61-62.

50 A közelmúltban például egy 14. századi, európai darabot vizsgálva jól el lehetett különíteni egymástól az alacsony és magasabb réztartalmú, egy oldalon aranyozott ezüstfonallal készült részleteket a fonalak „megjelenése” és a hímzéstechnika alapján is (nem publikált eredmények).

51 Ld. pl. LeWIS 1763, 52-53; KrüNITZ IX, 1776, 469. (Draht címszónál); WeiszBuRg et AL. 2017, 10758. 
században leírt ún. reakcióforrasztás ${ }^{52}$ szintén szóba jöhet az előbbi kettő mellett. ${ }^{53}$ Modellkísérletek és mérések cáfolhatják vagy támaszthatják alá az említett aranyozási eljárások alkalmazását e fémfonalak készítése során. Az aranyréteg vastagsága a szalagok felületén, a közelmúltban végzett mérések alapján, néhány ezred milliméter. ${ }^{54} \mathrm{~A}$ jelenlegi rétegvastagság nem csak az aranyozás mikéntjétől, hanem a textília használati kopásától, az egykori, illetve a későbbi századokban végzett tisztítások számától és módjától is függ. (Ezért nem rekonstruálható a felület eredeti színe.)

Az egy oldalon aranyozott ezüstfonalat összesen négy tárgyról vett nyolc minta reprezentálja az elemzett anyagban. ${ }^{55} \mathrm{~A}$ szalagokat halványsárga/sárga selyemfonalra fonták szorosan, balról jobbra, azaz $\mathrm{S}$ sodratban (Id. pl. 4. ábra 1.). Az ezüst alap minden esetben tartalmaz rezet, a szalag belső felületén mért értékek 2-8\% között változnak. Az aranyozott külső felületen 2 és 7\% közötti rézkoncentrációt mértünk, ${ }^{56}$ higanyt nem tudtunk detektálni.

A két oldalon aranyozott ezüstfonal a 14. században már bizonyíthatóan ismert volt Közép-Ázsiában. ${ }^{57}$ Európában, eddigi ismereteink szerint, kb. a 16. század közepétől kezdett elterjedni, és kezdetben minden valószínűség szerint importáru volt. Mintegy száz esztendőn keresztül párhuzamosan használták szövéshez és hímzéshez korábbi változatával együtt, majd a 17. század második felére, az analitikai elemzések alapján, ez vált az általánosan alkalmazott aranyfonallá. ${ }^{58}$ Feltételezésünk szerint valamikor a 16. század vége felé kerülhetett a gyártástechnológia is Keletről kontinensünkre. A török területeken viszont már a 16. századtól használták szövéshez, hímzéshez az eddigi adatok alapján. ${ }^{59} \mathrm{~A}$ szalagokat ebben az esetben nem lemezből vágták, hanem aranyozott ezüstdrótból hengerelték. Először egy vastagabb ezüstrudat aranyoztak, majd ezt fokozatosan vékonyították különböző húzóvasak segítségével, a Diderot-féle Enciklopédia 1756-os leírása szerint kb. nyolcvan lépésben. ${ }^{60}$ Csak ezután kerülhetett sor annak az igen vékony, 0,1 milliméternél jóval kisebb átmérőjű drótnak a húzására (szintén sok lépesben), amelyet megfelelően vékony szalaggá tudtak hengerelni. A drót készítéséhez, valószínűleg már a kezdetektől, főként kis réztartalmú ezüstöt használtak. Eddigi vizsgálataink során magasabb, 6\% körüli rézkoncentrációt csak egyetlen, korainak számító, 15. századra datált európai hímzésről származó mintánál mértünk. ${ }^{61}$ Az aranyozást forrasztóanyag nélkül aranyfüsttel, de esetleg aranyamalgámmal is végezhették. Az aranyréteg vastagsága a húzás során folyamatosan csökkent.

A vizsgált aranyozott ezüst hímzőfonalak nagyobb része, huszonhét tárgyról vett harmincnégy minta, ebbe a csoportba tartozik. A szalagokat sárga, ritkábban fehér (natúr, bézs) selyemfonalra fonták szorosan (Id. pl. 4. ábra 2.) vagy szakaszosan (ebben az esetben a fém nem fedte teljesen a selymet: riant fonási mód, Id. pl. 7. ábra b), S sodratban. Közülük mindössze kettőnél lehetett 1\% körüli réztartalmat detektálni, a többinél ezen érték alatt volt a réz koncentrációja, így valószínűsíthető a segédanyag nélküli aranyozás. Higanyt vagy nem lehetett kimutatni vagy csak 1\% alatti mennyiségben, kivéve egy mintát (6\% körül).

A két oldalon aranyozott ezüstszalagot bélfonal nélkül is használták, lamellaként, amelyet a 16. század második felétől gyakran szőttek szövetekbe. ${ }^{62}$ Hímzőfonalként történő alkalmazásáról nincsenek korábbi mérési adataink. A vizsgált minták között egy ilyen lamella volt, a szalag felületi rétegeiben csak nyomnyi mennyiségü rezet lehetett detektálni.

Az ezüstfonalak alulreprezentáltak az elemzett anyagban: hét tárgyról nyolc mintát elemeztünk, de műszeres analízist csak négy esetben végeztünk, a többit nedvesanalitikai módszerrel azonosítottuk. Az előbbi mintákban a réztartalom nem haladja meg az 1\%-ot.

Ezüst lamella egy volt a vizsgált hímzőfonalak között, de több tárgyon is előfordult.

52 Rézvegyület és szerves anyagok keveréke a forraszanyag. THEOPHILus 1986, 127. (Ld. ugyanerről, többek között, Brepohl fejtegetését is, BREPOHL 1987, 236.)

53 A Weiszburg és munkatársai által végzett komplex elemzések nem igazolták tűziaranyozás, illetve rézforrasz használatát egy válogatott mintasor esetében. WeIszBURG et AL. 2017, 10753-10760.

54 Weiszburg et al. 2017, 10757.

55 Ez is alátámasztani látszik, hogy ebben az időszakban már a modernebb, egyszerübben eloállítható, drótból hengerelt aranyozott ezüstszalagot használták a fonalkészítéshez.

56 A réz mennyisége az arany és az ezüst mellett értendő. Az alkalmazott módszerrel nem állapítható meg, hogy mennyi ebből az aranyréteg réztartalma és mennyit detektált a műszer az alap ezüst-réz ötvözetből. A kisebb gerjesztőfeszültséggel végzett elemzések eredményei és az egykorú források adatai (vö. pl. BoIzARD 1692, 61-62.) azt mutatják, hogy finomított, közel 24 karátos aranyat használtak a borításhoz.

57 Járó 2010a, 136-142.

58 Ld. pl. a táblázatos összefoglalót: JÁRó - TóTH 2013, 37-39. (1. és 2. táblázat)

59 JА́RÓ - То́тH 2013, 39-43.

60 Ld. a FlLERE, terme de Tireur d'Or címsZónál. ENCYCLOPÉDIE VI. 1756, 800.

61 A minta a hímzés többi részétől eltérő „megjelenésű” részletről származik, a szalag vastag, rideg. Jelenleg úgy gondolom, hogy egy „helyi próbálkozás" lehetett az egyszerübben elóállított, import fonalak utánzására a hagyományos aranyozási eljárással (rézforrasz vagy magasabb réztartalmú ezüst alkalmazásával). Publikálatlan.

62 Ld. pl. az összefoglalót: JÁRó - ТótH 2013, 37-39. (1. és 2. táblázat) 


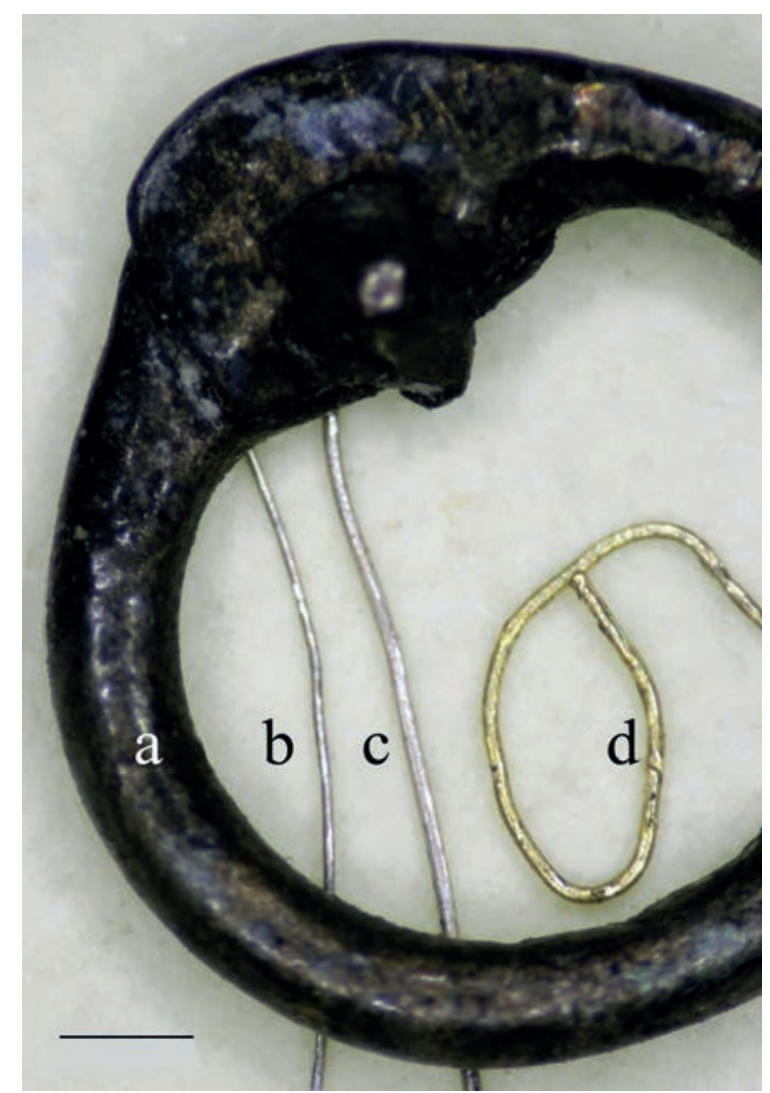

5. ábra. Drótok, skófiumok. Optikai mikroszkópos felvétel, marker 0,5 mm

a. Drótkarika (II. Rákóczi György fejedelem díszsodronyinge, Erdély, 17. század közepe);

b. Ezüst szövődrót letisztítva (itáliai szövet, 17. század); c. Igen kopott aranyozású ezüst- vagy ezüst hímzőskófium letisztítva (terítő, Erdély, 17. század első negyede, a 6. ábrán látható motívum fémfonala); d. Aranyozott ezüst hímzőskófium letisztítva (terítö, Erdély, 17. század második harmada)

\section{Aranyozott ezüst-, illetve ezüstdrótok/skófiumok}

Az általunk ismert leírások, katalógusok és mérési adatok alapján a drót a 16. század elejétől mutatható ki szövőfonalként európai textíliákon. ${ }^{63}$ Készítésmódját az előző részben már tárgyaltuk. A különbség talán annyi, hogy a hímzőskófiumok 0,08-0,10 milliméter vékonyra húzott drótok, vagyis eddigi méréseink alapján „vastagabbak", mint a szövéshez, illetve a fémszalagok készítéséhez használtak (Id. pl. 5. ábra b, illetve c és d).

Tizenhárom hímzésről vizsgáltunk egy-egy aranyozott ezüstskófiumot. Rezet a drótok felületi rétegében, illetve esetenként a keresztmetszeten, nem vagy csak 0,5\% alatti mennyiségben lehetett kimutatni. A mért higanykoncentráció 0-1,5\% között mozgott, egy mintában volt csak magasabb, 5\% körül. Ez utóbbi skófium ugyanarról a nyeregről ${ }^{64}$ származik, amelynek két oldalon aranyozott ezüstfonalán is magasabb higanytartalmat mértünk. Itt térnénk ki arra, hogy II. Rákóczi György fejedelem 17. század közepére datált, Erdélyben készült díszsodronyinge készítéséhez kb. fél centiméter átmérőjü drótkarikákat használtak (5. ábra a). ${ }^{65} \mathrm{E}$ karikák kb. 0,5-0,6 milliméter vastagságú, nagy valószínűséggel tűziezüstözött sárgaréz drótból készültek, vagy utólag ezüstözték azokat. ${ }^{66}$ Egy másik, hasonló, ugyanebből a korszakból származó sodronyingről ${ }^{67}$ más formájú, drótból lapított karikát elemeztünk. Ennek is sárgaréz az alapanyaga, és ezüstrétege szintén tartalmaz higanyt. ${ }^{68} \mathrm{~A}$ bevonat, pontosabban az ezüstöt tartalmazó réteg a legvastagabb részen mindkét esetben kb. 0,01 milliméter. ${ }^{69}$ Többek között ezért véljük úgy, hogy az amalgámos módszert használhatták aranyozott ezüstdrótok készítésénél is, legalábbis egyes területeken, mühelyekben. A változó higanykoncentráció (vagy a higany hiánya) az ezüstözés/aranyozás technikájától, a higany elűzéséhez szükséges kimelegítések hőmérsékletétől és számától egyaránt függhet. A vonatkozó szakirodalom alaposabb tanulmányozása és újabb, célirányos elemzések segíthetnek a módszer rekonstruálásában.

Aranyozott ezüstdrótból készült fonal („skófium aranyfonal, tekert skófium”) a vizsgált magyar anyagban nem volt, viszont török hímzéseknél találkoztunk ilyen fémfonallal. ${ }^{70}$

Ezüstdrótot négy tárgyról vett öt minta esetében elemeztünk, de ennél sokkal gyakrabban fordul elő a hímzéseken. Közülük két, ugyanarról a terítőről származó skófiumot műszeresen, a többit csak klasszikus módszerekkel vizsgáltunk. Az analizált mintákban rezet nem lehetett kimutatni viszont kevés aranyat (0,5-1,5 \%) és higanyt (kb. 1-1,5\%) igen. ${ }^{71}$

63 JÁRÓ - TÓTH 2013, 37-39. (1. és 2. táblázat)

64 A nyereg a 17. század közepére datált. EsterhÁZY GYüJTEMÉnYı SZAKKATALÓGus II. 2010, Kat. 34. László Emőke leírása.

65 Kovács S. 2010, 248, illetve 147. kép

66 A mérések még a múlt század kilencvenes éveiben történtek, ezzel a kérdéssel akkor nem foglalkoztunk. Köszönettel tartozom Prim József fém-ötvös restaurátornak, a Hadtörténeti Intézet és Múzeum munkatársának, hogy segített végiggondolni a készítéstechnika lehetséges változatait. Nem kizárt az sem, hogy a higany az ezüst kinyerése során került a nemesfémbe.

67 KovÁcs S. 2010, 249, illetve 168. kép

68 A keresztmetszeteken történt EDS analízis alapján a réz mindkét esetben $\mathrm{kb}$. 20\% cinket tartalmaz. Az ezüstrétegben (a keresztmetszet-csiszolaton) a Rákóczi sodronyingnél kevés, míg a másik mintánál $9 \%$ higanyt mértünk ( $80 \%$ ezüst, 10\% réz és $1 \%$ cink mellett).

69 A keresztmetszetről készült, ezüstspecifikus, pásztázó elektronmikroszkópos felvételen mérve.

70 Ld. pl. Esterházy GyüjtemÉnyı SZAKKatalóGus II. 2010, Kat. 46, 224. (a „török csomó” a paszomány részeként), Kat. 47. 228. (a gombkötő munkáknál)

71 A két fém jelenlétének magyarázatához további vizsgálatok szükségesek. 


\section{Rézalapú fonalak}

Az adott időszak írásos dokumentumai nagy valószínűséggel e fémfonalakat említik réz, hamis arany-, illetve ezüstfonal, lyoni arany/ezüst vagy síkként. Elsősorban a szegényebb rétegekhez tartozók öltözetén, háztartásában játszottak szerepet, ${ }^{72}$ így az átnézett forrásokban viszonylag ritkán fordulnak elő. Készítésmódjukkal korábban részletesen foglalkoztunk. ${ }^{73}$

A réz megjelölés, az eddigi vizsgálatok alapján, inkább rézötvözet alapanyagra utal, például sárgarézre. Szín-, azaz vörösrézből készült fonallal eddig csak nagyon ritkán találkoztunk, és ezekben az esetekben is mindig felmerült, hogy a nemesfémborítás lekophatott a felületről. A hamis arany, illetve -ezüst arany- vagy ezüstszínű, rézalapú szalagból készült fonalat vagy drótot jelez. A sík valószínűleg ugyanezekre vonatkozik, ${ }^{74}$ ugyanúgy, ahogy a lyoni arany/ezüst is, de ezen elnevezésekkel kapcsolatosan is további kutatások szükségesek. A síkos arany például lehet az ellapított sárgaréz drót vagy akár az aranyozott ezüstdrót, azaz lamella is. A fényes sík talán a jó állapotú, hamis arany- vagy ezüstdrótot/fonalat, esetleg lamellát jelöli. A vont sík fonal, mint áru a sárgaréz szalag vagy drót bélfonalra font változatára utalhat.

Az általunk vizsgált anyagban mindössze két rézalapú fonal fordult elő. Az egyik egy pamut bélfonalra $Z$ sodratban font rézszalag kb. 10\% cinktartalommal. Az újkorában aranynak tűnő fonal talán egy későbbi javítás „emléke”. A másik egy szögletes, ezüstözött majd aranyozott vörösréz drót, amelyet többszörösen meghajlítva bouillon-hímzéshez használtak. ${ }^{75}$

\section{Kísérlet a leltárakban szereplö, további fémfonal-változatok értelmezésére}

A fényes arany meghatározást az anyagvizsgálatok alapján egyelőre csak úgy tudjuk értelmezni, hogy jó állapotú, csillogó aranyat írt le ilyen módon a leltározó, míg a fehér fényes arany ennek vékonyabb aranyozású, sápadtabb, inkább ezüstös színű változata lehet. A fehér és sárga skófium az ezüst-és aranyozott ezüst hímződrótra, míg a sárga klabodán nagy valószínűséggel aranyozott ezüstfonalra utal. A magyar és a török arannyal/ezüsttel alább, az Összegzés című rész külön fejezetében foglalkozunk, és visszatérünk még a klabodánra is.

\section{Összegzés}

A történeti források tanulmányozása és az archeometriai vizsgálatok eredményei alapján körvonalazódott az a 17. századi fémfonal-csoport, amely a magyar területeken, a gazdagabb réteg által használt hímzőfonalakat foglalja magába. Ennek ismeretében vizsgáltuk, hogy a leltárakban szereplő „magyar”, illetve „török” jelzők a fonalak eredetére vagy valamely más, karakterisztikus jellegzetességére utalnak-e.

\section{Készültek-e fémfonalak a Magyar Királyság, illetve Erdély területén?}

A hímzőfonalak iránti igény indokolta volna, hogy fémfonal-készítéssel foglalkozó mesterek tevékenykedjenek a három részre szakadt ország területén és nevük megjelenjen egy-egy dokumentumban. Ennek ellenére nem találtunk eddig olyan 17. századi forrást, amelyben hazai mestert vagy mühelyt említettek volna. Ugyanakkor utalások vannak arra, sajnos egyelőre csak a vizsgált korszak előtti, illetve utáni időkből, hogy működtek kisebb, egy- vagy néhány fős „vállalkozások" amelyek elsősorban a királyi, fejedelmi udvarokat vagy az azoknak dolgozó múhelyeket látták el fémfonallal. ${ }^{76}$

Nem találtunk adatot arra sem, hogy valamely hazai céh tagjaként dolgozott volna skófiumhúzó vagy aranyfonó az adott időszakban. Ez természetesen nem zárja ki, hogy egy-egy mester fémfonal-készítésre „,szakosodott” például olyan céhben, amelyeknek tagjai, „feldolgozták” a fémfonalakat (például a hímvarrók, gombkötők, paszományosok stb.) vagy ötvös céhben tevékenykedett. Mindenesetre az ötvösök által a „drótmunkákhoz” húzott drót vastagabb volt, mint a skófium. Az előbbit nem lehetett finom hímzéshez, az utóbbit pedig például lánc vagy filigrán készítéshez használni. A hajszálvékony drót húzásához speciális dróthúzó-vasra/vasakra és nagy-nagy szakértelemre valamint gyakorlatra volt szükség, ahogy a drót szalaggá hengerléséhez is.

Az eddigi adatok alapján tehát úgy tűnik, hogy helyi készítésű, magyar eredetűnek tekinthető arany- vagy ezüstfonal nem, vagy csak lokálisan volt forgalomban az ország területén. Az 1600-as években hímzéshez, nagy valószínűséggel, importból származó fémfonalakat használtak. Ezt támasztják alá az archeometriai vizsgálatok eredményei is. Az elemzett, aranyszínű fonalak, a két rézalapú kivételével, aranyozott ezüstből készültek, igaz más-más technológiával. A minták nem mutatnak külön alcsoportokra utaló alaktani vagy anyagösszetételbeli

72 Temetők ásatási anyagában találkoztunk például viszonylag sok rézalapú fonallal. JÁRó - TóTH 1994.

73 JáRó 2009, 25-43.

74 Ld. RAdVÁnszky I. 1896, 87. Ezt támasztja alá például az 1701-es ungvári leltár következő tétele is: „...Tres rotulae auro et argento falso obletae vulgo Sik", BarAnYAI - CSERnYÁNSZKY 1984, (fasc. 107/44) 547.

75 Ld. Járó 2010b, 64-65, ill. 17. kép

76 Ld. pl. Simonello aranyfonó mestert, aki 1489-ben telepedett le Budán (V. EMBER 1980, 9.), és minden valószínűség szerint elsősorban Mátyás király udvarának készített fémfonalat. A valószínűleg német származású Gantzaug János skófiumhúzó Bártfán tevékenykedett a 18. század elején (Thaly 1879, 347.), ugyanúgy, ahogy azok a mesterek, akik II. Rákóczi Ferenc fejedelem udvarának dolgoztak Munkácson (Thaly 1883b, 388.). 
jellegzetességeket. Ugyanez mondható el az ezüstfonalakról valamint az aranyozott ezüst-, illetve ezüstdrótokról, skófiumokról is. A magyar hímzések fémfonalai, a műszeres vizsgálatok alapján, hasonlóak az adott korszakban, Európában, illetve oszmán-török területeken használt „társaikhoz".77

\section{Az importfonalak eredete és beszerzési helye}

Ha kronológiailag tekintjük át a tanulmányozott, gazdasági jellegú iratokat, akkor legkorábbi emlékként Buda város árszabását említhetjük 1522-ből. Ebben (még) megjelölték a fémfonalak készítési és/vagy beszerzési helyét, például velencei, milánói, firenzei aranyfonalról írtak. ${ }^{78}$ Észak-Itália a középkori selyemszövés egyik központja volt, a múhelyek mellett fémfonal-készítő manufaktúrák is működtek (pl. Lucca, Velence, Genova stb.). A 16-17. században e manufaktúrák újabb és újabb technológiákat alkalmazva folytatták tevékenységüket, és ugyanúgy, ahogy korábban is, nem csak a szövőműhelyeket látták el a szükséges fonalmennyiséggel, hanem az európai és távolabbi piacokra is szállítottak fémfonalat. Mellettük más országokban is kialakultak hasonló, nagyobb „üzemek”, így például Lyonban vagy Nürnbergben. Elsősorban ezekből a centrumokból kerülhetett az áru a föbb „elosztóhelyekre”, piacokra, így Bécsbe is. Számos adat utal arra, hogy a Habsburg Birodalom fővárosában vásárolták a szükséges fémfonalak jó részét a Magyar Királyság és az Erdélyi Fejedelemség főurainak, gazdagabb polgárainak a 17. században. Erről tanúskodnak, mások mellett, a Thurzó család négy nőtagjának házasságkötése előtt „Bécsben tett" vásárlások dokumentumai 1603 és 1618 között. ${ }^{79}$ Innen vittek arany- és ezüstfonalat Kolozsvárra is, legalábbis a század első harmadában, 1599-től 1635-ig. ${ }^{80}$ Később is vettek Bécsben fémfonalat, például Csáky István országbírónak 1666-ban ${ }^{81}$ vagy Haller Jánosnak 1685-ben, ${ }^{82}$ hogy csak néhány erre történő utalást említsünk.

Talán a korszak másik fő beszerzési helye (magyar vonatkozásban mindenképp) Konstantinápoly lehetett. Innen származó fémfonalként jelölték a skófiumot, az átnézett, 17. századi forrásokban először az 1618-as kolozsvári harmincadjegyzékben. ${ }^{83} \mathrm{~A}$ későbbiekben is folyamatosan szállítottak a Török Birodalom fövárosából hímződrótot az erdélyi városba. A Bethlen Gábor fejedelem által 1627 áprilisában aláírt árszabásban a „görög marhák", míg az ugyanezen év októberében kelt limitációban a „Török, görög és zsidó kereskedőktől behozandó marhák" között szerepelt. ${ }^{84}$ Alig találtunk említést viszont arról, hogy a skófiumon kívül arany-vagy ezüstfonal (sárga- és fehér klabodán néven) is érkezett volna onnan.

Bécs és Konstantinápoly mellett ritkábban feltúnnek további városok is, például Krakkóo ${ }^{85}$ vagy Velence. ${ }^{86}$ E két utóbbi város kereskedői a helyben készült(?), illetve nyugat- és dél-európai eredetű fonalak mellett keletről jött árukat is kínálhattak, ahogy ez nagyon valószínű Bécs és Konstantinápoly esetében is.

\section{A „magyar" és a „török" arany valamint ezüst 17. századi magyar hímzéseken}

A 17. századi árszabásokban, számadáskönyvekben, az elvámolt áruk jegyzékében csak elvétve találkoztunk az arany-, illetve ezüstfonalak eredetére vonatkozó információval. A ritka kivételek között említhetjük például, azt a "6 font olasz arany fonalat...", amelyet 1624-ben Bethlen Gábor fejedelem udvartartása számára Bécsben vettek $^{87}$ vagy az I. Rákóczi György fejedelem részére 1646-ban Konstantinápolyban beszerzett klabodánt. ${ }^{88}$ Ugyanakkor a hímződrót elnevezése a skófium, habár nem török szó, ${ }^{89}$ közvetve utalhatott arra, hogy keleti, nagy valószínséggel török portékáról van szó.

A fent említett vásárlási, vámolási stb. jegyzékektől eltérően a hozomány- és hagyatéki leltárak és más öszszeírások közül közel harmincban előfordul a magyar és/vagy török eredetjelző..$^{90} \mathrm{~A}$ lajstromozók, mivel nemigen tudták, hogy hol készült a fémfonal, sőt feltehetően azt sem, hogy hol vásárolták, valószínüleg valamilyen szabad szemmel észrevehető jellegzetességet akartak kiemelni, amikor e jelzőket alkalmazták. Sajnálatos módon, ahogy ezt már korábban említettük, a korszak fémfonalas hímzéseit, azok színét olyannak, mint amilyennek az összeírók látták többé már nem láthatjuk, és a felületi rétegek összetétele, az aranyozás vastagsága sem

\footnotetext{
77 Az összehasonlításhoz több, mint ötven, 16-17. századra datált európai és több, mint negyven oszmán-török szövetről, hímzésről, paszományról származó, közel száznegyven, általunk elemzett minta vizsgálati eredményeit vettük figyelembe.

78 „....auro filato Veneciano....", „....auro filato Mediolanensi vel Florentino...", KEMÉNY 1889, 377.

79 RaDVÁnsZKY II. 1879, 112, 143, 200, 210.

80 Az első, 1599-ből származó bejegyzést Id. PAP 2000, 107. és egy 1635-ből származót PAP 2000, 486.

81 DЕÁK $1883,588$.

82 SZABÓ $1878,681$.

83 PAP 2000, 290.

84 ERdélyı OrszÁGgyülésI EmlékEK 1882, 384, illetve 442.

85 Ld. pl. RADVÁNSZKY $1888,66$.

86 Ld. pl. RadvánsZky 1888, 70; Barabás 1881, 181-182.

87 RADVÁNSZKY 1888, 74.

88 Beke - Barabás 1888, 818.

89 Vö. PÁszToR 1997, 36.

90 Az átnézett, többféle fémfonalat is említő összeírások kevesebb, mint 10\%-a.
} 
ugyanolyan már, mint akkor volt. Figyelembe véve továbbá, hogy a leltározók nem egységes nómenklatúrát használtak, valamint sem az átnézett dokumentumok, sem pedig a „találatok" száma nem elegendő sem statisztikai kiértékeléshez, sem pedig messzemenő következtetések levonásához, az alábbiakban egy hipotézist próbálunk felvázolni.

Abból indultunk ki, hogy a skófium elnevezés már a 16. században is előfordult, ${ }^{91}$ majd később általánossá vált a hódoltság kori Magyarország területén, fokozatosan "kiszorítva” a hímzőfonalak esetében a drót valamint a vont arany és -ezüst meghatározásokat (az utóbbiakat, ha áruról volt szó). Mivel az idegen hangzású szó nemcsak e fémfonal morfológiájára, hanem, ahogy már említettük, eredetére is utalhatott, úgy gondoljuk, hogy a „magyar" megjelölés nem vonatkozhatott drótra. A másik gyakori alaktani változat, a bélfonalra font fémszalag volt. Feltételezésünk szerint ezek között kell a „magyar" és esetenként a „,török" eredetjelzővel szereplő fémfonalakat keresnünk.

A drótot és a fonalat szabad szemmel és/vagy tapintással is meg lehetett különböztetni egymástól, ha valakinek jó szeme volt és rendelkezett némi jártassággal a fémfonalak tekintetében (Id. pl. 6. ábra). Érdekességképp ez utóbbiak hiányát tűnik felróni az 1651-es diószegi leltár készítője, amikor ezt írja: „Tizenkét bokor vitéz keotéshez arany fonallal szőtt virágos mentére való gombok. Ezeket maga szegény Szkófiomosoknak írta volt." 92 Vagyis (értelmezésünk szerint) Gelli kapitány, akinek ingóságait valószínúleg halála után lajstromozták, a maga készítette, korábbi leltárban a fonalat drótnak nézte.

A „magyar arany" kifejezéssel eddig huszonhárom lajstromban (tizenegy hozományjegyzék és tizenkét leltár) találkoztunk, ${ }^{93}$ közöttük van észak-magyarországi (pl. Szepes vára), nyugat-magyarországi (pl. Kismarton) és erdélyi (pl. Szeben) egyaránt. A legkorábbi, általunk ismert dokumentum, amelyben említik Monaki Erzsébet 1630-as hozományjegyzékét, a legkésőbbi pedig a Csáky István halála után maradt ingóságok lajstroma 1685ből. „Magyar ezüstöt” e huszonhárom irat közül hétben (két hozományjegyzék és öt inventárium) említenek, ${ }^{94}$ és szerepel egy további hagyatéki leltárban „önállóan" is. ${ }^{95}$

Ha megvizsgáljuk a huszonhárom összeírást, mindegyikben használják a "magyar arannyal" párhuzamosan az „ arany" vagy az „,aranyfonal" megjelölést is. Amennyiben ez nem a lajstromozó következetlenségének az eredménye, akkor e fonalak között volt valamilyen látványbeli eltérés. Minek alapján vethette papírra például Károlyi Éva hozományjegyzékének készítője 1643 februárjában a következőket: „Vánkos hijaknak száma: Két vánkos hij, fényes aranynyal varrott. ... Két török varrásos, ágakba magyar aranynyal varrott vánkos híj. Két török varrásos, rózsákkal, arany fonállal varrott... Egy fejér varrással, arany fonállal varrott..." ${ }^{96} \mathrm{~A}$ "magyar arany" az idézett dokumentum szerint, úgy tủnik, nem a csillogó felületet, a "fényes aranyat" jelentette ${ }^{97}$ és különbözött a többi „aranyfonaltól” is. Továbbra is maradva a feltételezéseknél, színbeli eltérésre gondolunk. Ha a leltározónak a hímzés látványa, például a korszakban méltán híres magyar arany fizetóeszközt (forintot, dukátot), annak a finom aranyéhoz hasonló, kissé mattult, sötétebb sárga színét (és esetleg annak aranyozáshoz történő felhasználását ${ }^{98}$ ) juttatta az eszébe (vagyis vastagabb aranyozású ezüstöt látott), magyar aranyként írhatta le azt (Id. pl. 7. ábra dés összehasonlításul e és f). Magyar ezüstnek a nem, vagy csak kevéssé sötétedett ezüstfonalat ${ }^{99}$ nevezhették (Id. pl. 7. ábra c).

A török jelzőt fémfonallal kapcsolatosan mindössze hat leltározó használta az eddig átnézett összeírásokban (három hozományjegyzék és három leltár). ${ }^{100} \mathrm{~A}$ legkorábbi Thurzó Mária hozományjegyzéke 1612-ből, míg a legkésőbbi az 1693-as Esterházy leltár. Ezen iratok között is van észak-magyarországi (pl. Trencsén), nyugatmagyarországi (pl. Kabold), de eleddig nem akadtunk erdélyire.

A hipotézis felállításához tehát negyedannyi adat állt rendelkezésünkre, mint a "magyar" fémfonalak esetében, ezért feltevéseink valószínüleg még kevésbé megalapozottak, mint az előző esetben. Mindenesetre a skófium szó használata a 17. században, ahogy már írtuk, feltehetően egyértelmúsítette e fémfonal keleti/török eredetét, ,"örök skófium" meghatározással nem találkoztunk.

91 Ld. pl. Radvánszky II. 1879, 83.

92 Baranyal - CsernYÁnsZkY 1984, (fasc. 102/30) 78.

93 Ld. Bártfal Szabó 1919, 751-758, 759-766; Esterházy Inventarium 1642, 6; Géresi 1887, 263-273, 416-423, 459-464; KomÁromy 1886, 150 181; Комáromy 1891, 683-688; КомÁromy 1896, 437-444; Lukinich 1908, 12-24; RadVÁnszky II. 1879, 253-256, 268-271, 277-286, 304-307, 311-315, 337-341, 348-351, 351-355; Thaly 1873, 686-688, 688-701; Thaly 1900, 323-328; BARANYAl - CSERNYÁnSZKY - BARACKA 1975, 283285; VINCZE 1878, 940-949.

94 Ld. Báttfal Szabó 1919, 751-758, 759-766; Géresi 1887, 459-464; Radvánszky II. 1879, 277-285, 351-358; Komáromy 1886, 150-181; Baranyal - CSERNYÁNSZKY - BARACKA 1975, 283-285.

95 RadvánsZKY II. 1879, 325-330.

96 GÉRESI 1887, 271.

97 Más leltárakban is megkülönböztették a kettőt, Id. pl.: RADvánszky II. 1879, 255.

98 Krünitz Enciklopédiájában például a „magyar- vagy dukátaranyat” mint aranyozáshoz általánosan alkalmazott, 23 karátos (kb. 960 \%o-es) aranyötvözetet említik. KRÜNITZ XIX.1788, 501 (Gold=Fabrik címszónál).

99 Egyelöre nem tudjuk, milyen technológiai lépés (esetleg a felület nem csak húzás közbeni, hanem utólagos viaszolása?) eredményezte, hogy egy-egy ezüstfonal hosszú ideig megőrizte eredeti színét.

100 Ld. Radvánszky II. 1879, 149-155, 277-286, 325-330; Szerémi 1880, 195-201; Baranyal - Csernyánszky 1981, (fasc. 89/13) 8-11; Esterházy INVENTARIUM 1693. 
Az Árva várában 1670-ben összeírt ingóságok között két csomag/köteg (még fel nem használt vagy maradék) fonal szerepel önálló tételként. ${ }^{101} \mathrm{~A}$ latin meghatározás talán húzott/vont török arany- és ezüstfonalként fordítható és bélfonalra sodort drótként értelmezhető. A drótra a "vont" megjelölés utalhat. A skófium kifejezés nem fordul elő a rendelkezésünkre álló szövegben, említenek viszont török húzott (vont) aranyat száras gombbal kapcsolatosan, ${ }^{102}$ ami vélhetően az aranyozott ezüstdrótot, vagyis a skófiumot jelentheti. A lajstromozó tehát valószínűleg a drótot, illetve az azzal készült fonalat nevezte töröknek. A további öt dokumentum közül háromban említik a skófiumot is, így ezeknél talán feltételezhetö, hogy a "török arany és ezüst" ${ }^{103} \mathrm{a}$ "török arany", 104 illetve a ",örök fonal"105 bélfonalra font szalagot jelöl. Esetleg igaz lehet ez a további két jegyzék esetében is, amennyiben Thurzó Borbála ${ }^{106}$ és Thököly Mária ${ }^{107}$ kelengyéjében például nem volt skófiummal hímzett darab. Ahogyan a "magyar arany" esetében, itt is felmerül a kérdés, hogy mi különböztethette meg a török fonalat a többitől? Véleményünk szerint a „török" jelzős arany- és ezüstfonal nagy valószínűséggel $a$ selyem bélfonalra szakaszosan font, ezüst-, illetve két oldalon aranyozott ezüstszalag lehetett. A klabodán szó valószínúleg szintén ezt a típust jelöli. A szakaszos fonás szabad szemmel is látható, ha gondosabban szemügyre vesszük a textíliát. ${ }^{108}$ Vastagabb, fehér selyemre font, ezüst változatával (ld. pl. 7. ábra a) szőtték az ún. serâser szöveteket. ${ }^{109} \mathrm{Az}$ aranyozott ezüstfonalak bélfonala sárga selyem (ld. pl. 7. ábra b), és a szövetbe szőve inkább csak a mintázat területén „jelentek meg”. Az Oszmán Birodalomban már a 16. századtól használták szövéshez mindkettőt, ${ }^{111}$ és alkalmazásuk a későbbi századokban is kimutatható, hímzéseken is. ${ }^{112}$ Adataink alapján ritkán ugyan, de előfordul 16-18. századi, európaiként számon tartott szöveteken, illetve hímzéseken, közöttük például a vizsgált anyagban, egyes 17. századi magyar terítőkön. Ez utóbbi esetekben feltételezzük, hogy török fonalat használhattak. Találkoztunk szakaszosan font, aranyozott ezüst- és ezüst fátyolfonalakkal (fehér bélfonallal) középkori, európai szöveteken ${ }^{113}$ és egy oldalon (vastagon) aranyozott ezüstszalaggal készült fémfonallal 15. századra datált itáliai darabokon is. ${ }^{114}$ Ez felveti a kérdést, hogy ténylegesen török "találmány" volt-e, vagy Európából került török területekre, esetleg Keletről, például a perzsáktóol15 vették át mindkét helyen az ötletet. Mindenesetre az eddigi adatok alapján úgy tűnik, hogy a vizsgált időszakban főként török (vagy a tőlük a mesterséget elsajátító, más nemzetiségü,

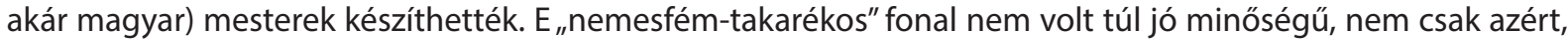
mert a fémszalag nem fedte teljesen a bélfonalat (bár a riant fonás szolgálhatott esztétikai célt is), hanem mivel mindkét változata gyorsabban sötétedett, korrodálódott. Egy 1709-ben írt levélben olvashatjuk: „„...azon feketés ezüstfonalat, melyet a törökök csinálnak, fordítsa Kgld a cavallérok tarsolyára és lóding-varratására, az ő Felsége számára pedig, ha a piaczon kell is venni, vétessen Kgld szépet...".116 II. Rákóczi Ferenc fejedelemről, és a neki, a munkácsi várhegy lábánál dolgozó mesteremberekről van szó, akik, egy másik, 1710-es levél szerint, ,"alábbvaló" aranyfonalat (is) készítettek. ${ }^{117} \mathrm{Az}$ idézetekből az derül ki, hogy azok az - egyébként a fejedelem által „behívott" - török(?) örmény(?) fémfonal-készítők ott és akkor nem tudtak minőségi árut elóállítani. Az aranyozott ezüstdrótból hengerelt szalagok felületén a vékony aranyréteg és/vagy az aranyozás módja, ${ }_{118}^{18}$ az ezüstökén talán valamilyen (más fonalnál, például a „magyarnál" meglévő) védőréteg-féle hiánya okozhat-

101 Item, fila aurea et argentea Turcica ductilia in fasciculis no. 2..." BARANYAI - CSERnYÁnsZKY 1981, (fasc. 86/35) 10.

102 Item latorum vulgo Szaras gomb aureo Turcico ductili et serico caeruleo intertexta..." BARANYAI - CSERnYÁnsZKY 1981, (fasc. 86/35) 11.

103 Ld. a cím alatt szereplő, második idézetet és a 3. lábjegyzetet.

104 Ld. pl. „Veres karmasin színü bársony, török arannyal varrott gyöngyös szoknya” SzERÉMı 1880, 197.

105 cum duabus Pharetris Filo Turcico elaboratae" [...két török fonallal készült tegez(zel)], EsterHÁzy Inventarium 1693, 77.

106 RADVÁnszkY II. 1879, 149-155. Édesapja, gróf Thurzó György kincstárának egy hónappal később készült összeírásában viszont szerepel a skófium, vagyis használták a kifejezést. RADVÁnsZkY II. 1879, 155-196.

107 Ld. a cím alatt szereplő, első idézetet és a 2. lábjegyzetet.

108 Ld. pl. egy oszmán-török dísznyereg selyemszövet-borításának részletét: EsterHÁZY GYüjtemÉnYı SzAKKaTAlógus II. 2010, Kat. 43., 215.

109 Ld. annak a dísznyeregnek a borító selyemszövetét, amelyből a 7. ábra „a” jelzetü mintája származik: ESTERHÁZY GYüJTEMÉNYI SZAKKATALÓGUS

II. 2010, Kat. 37., 198. vagy a 108-as lábjegyzetben említett szövetet. Ezeknél a fémfonal ún. lanszírozó vetülék (szövetszéltől szövetszélig fut). PÁszTOR 2010, 43.

110 Talán takarékossági okokból brosírozó vetülékként használták. Ld. a két fonal (arany és ezüst) együttes megjelenését ugyanazon a török sZöveten: EsteRHÁZY GYüJTEMÉnYI SZAKKATAlógus II. 2010, Kat. 2.

111 Ld. bársonyoknál: BRüsszelı KATALógus 2004, Kat. V.1.3, V.1.5. stb. valamint saját, publikálatlan adatok

112 Ld. RinuY 1995, 18-19.

113 A fátyolfonalak aranyozott ezüst- vagy ezüstfüsttel borított állati bélből vágott szalagok fehér lenfonalra fonva. Szakaszosan font változataikra példákat Id. Járó 1988, 11, 12, 15. kép

114 Saját, publikálatlan adatok.

115 Elemeztünk közel-keleti, illetve perzsa eredetűnek tartott szövetekről vett ilyen fonalakat is.

116 THALY $1883 a, 198$.

117 Thaly 1883b, 388

118 Közülük többnél 1\% vagy annál kicsit magasabb higany koncentrációt mértünk a felületen. További elemzések szükségesek annak eldöntésére, hogy ez tűziaranyozásra utal-e, és ha igen, jellemző lehetett-e ennek a módszernek az alkalmazása az oszmán-török aranyfonalak esetében. 
ta a gyorsabb korróziót. Elképzelhető, hogy ez már a korábbi, 16-17. századi (keleti-török, szakaszosan font) fonalakra is érvényes volt. A készítést és/vagy egy-egy tisztítást követően, viszonylag rövid idő elteltével, már csak nehezen lehetett puszta szemrevételezéssel megállapítani, hogy a szürkés-feketés réteg a fémszalagon ezüstöt vagy aranyozott ezüstöt fed-e. ${ }^{119}$

A címben feltett kérdésre adott, hipotetikus válaszunk tehát az, hogy a 17. századi magyar hímzésekhez nem valószínű, hogy magyar területen készült fémfonalat használtak, viszont keleti/török eredetűeket igen. Feltételezésünk szerint egyes leltározók a vastagabb aranyozású, „igazi aranynak” látszó, bélfonalra font, aranyozott ezüstfonalat, illetve a jó állapotban lévő, nem sötétedett felületű ezüstfonalat írhatták le „magyarként”,

függetlenül attól, hogy a fonalak honnan származtak. A hímződrótot skófiumnak nevezve utaltak annak (vélt vagy valós) keleti/török eredetére. „Törökként” jelölték a szakaszosan, azaz riant módon font, két oldalon aranyozott ezüst- és ezüstfonalat, valamint a bélfonalra font drótot vagy egyéb, drótokból álló fémfonalat.

A kutatás korántsem mondható befejezettnek. Mind a készítőműhelyekkel, mind pedig a „magyar" és török" fonalakkal kapcsolatosan további forráskutatások és anyagvizsgálatok szükségesek.

A levéltári anyagban még rengeteg, ilyen szempontból feldolgozatlan dokumentum van, egyes összeírásokat pedig csak részben tettek közzé, így a teljesebb anyag tanulmányozását követően módosulhatnak a levont következtetések. A vizsgálati adatok számának növekedésével, a természettudományos módszerek tökéletesedésével, az új technikai megoldások alkalmazásával pontosabbá válhat a 17. században használt fémfonalakról, azok készítéstechnikájáról és eredetéről alkotott kép.

Végezetülálljon itt egy tétel egy 1685-ös leltárból:„Edgy igen szép eöregh aranyas Gyöngyös feödeles holyagos Kupa, kinek az teteyén edgy Királyné Aszony edgy Spectrumot [sic!] tart ${ }^{\prime 120}$ - Isten éltesse Költő Lászlót!

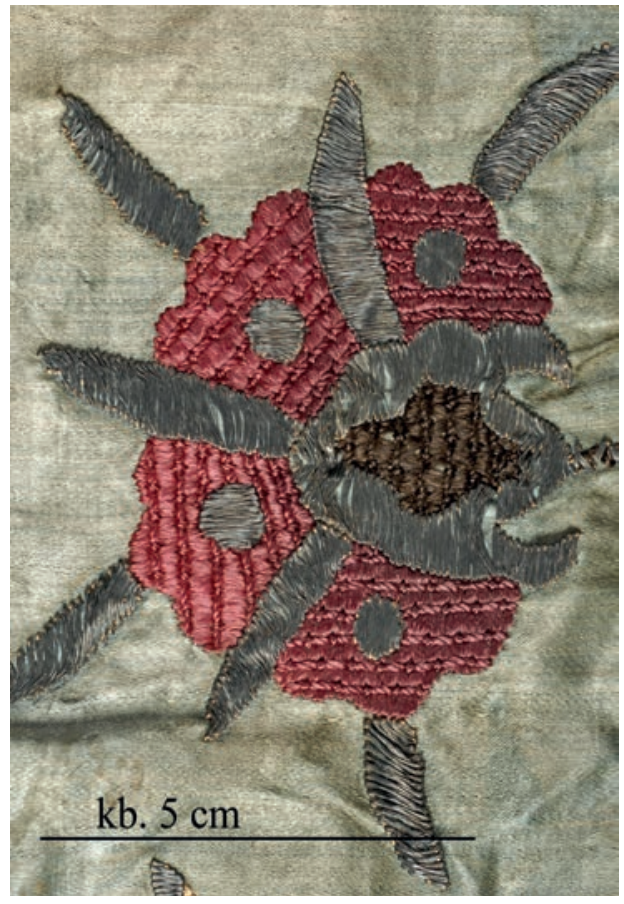

6. ábra. Az 1. ábrán látható ágyterítő egyik gránátalma-motívuma. A leltározó körülbelül ekkorának és talán színben is hasonlónak láthatta a hímzésrészletet (skófiumhímzés)

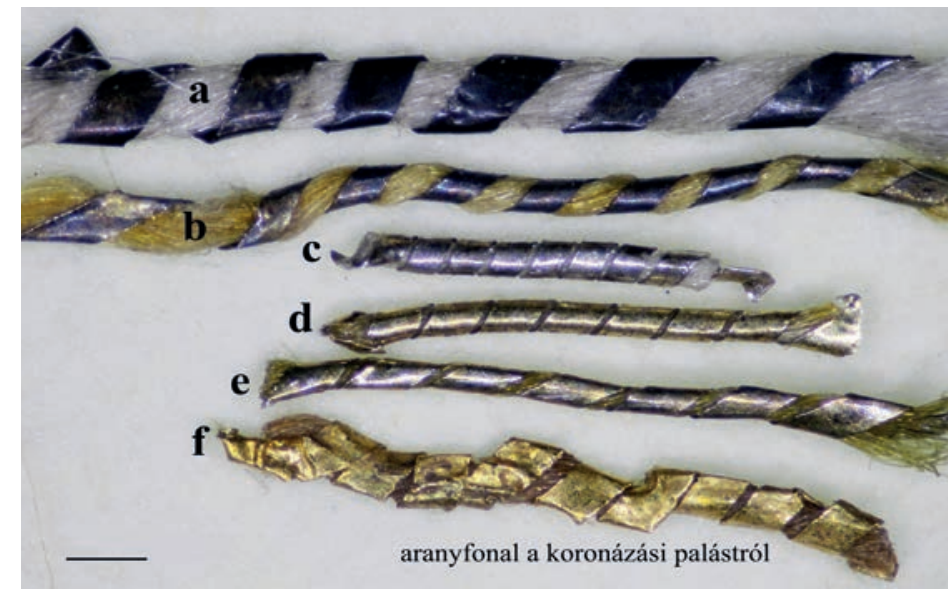

7. ábra. Aranyozott ezüst- és ezüstfonalak. Optikai mikroszkópos felvétel, marker 0,5 mm;

a. Szakaszosan font ezüst szövőfonal (oszmán-török dísznyereg selyemszövete, 17. század);

b. Szakaszosan font, két oldalon aranyozott ezüst szövőfonal (oszmán-török selyemszövet-töredék, 16. század vége); c-d. Ezüst-, illetve két oldalon aranyozott ezüst hímzőfonal (itáliai hímzés, 17. század eleje);

e. Két oldalon aranyozott ezüst szövőfonal (itáliai selyemszövet, 17. század második fele);

f. 23 karátos, igazi arany hímzőfonal a magyar koronázási palástról (11. század)

119 Esetenként a sárga bélfonal utalhat aranyozott ezüstre.

120 Nem tudni, a leltározó vagy a közlő írt sceptrum (kormánypálca) helyett spectrumot, esetleg a nyomda ördöge tette...(bárkivel megeshet!). Ld. EsTERHÁZY INVENTARIUM 1685M, 484. 


\title{
"Hungarian" and "Turkish" gold and silver threads - were they used in $17^{\text {th }}$ century Hungarian embroideries? The "palette of metal threads" of the period according to the contemporary written sources and the archaeometrical examination
}

\author{
MÁRTA JÁRÓ
}

The embroideries, made in the territory of Hungary in the $17^{\text {th }}$ century, were often decorated with special motifs created from Western and Eastern (mainly Ottoman-Turkish) elements. To make them more splendid, besides of silk, different metal threads were also used for the work. The provenience of the different threads is very rarely given in the contemporary purchase- and customs tariff-lists, regulations of prises, etc. However, in other types of documents like dowry lists, inventories we find sometimes the "Hungarian" and "Turkish" indications of origin in connection with metal threads. This problem has already been mentioned in the $20^{\text {th }}$ century Hungarian and foreign special literature, but not any explication was found for the denominations like "Hungarian gold", "Turkish silver", etc. The aim of the research was to make an attempt at the clarification of these terms by scientific methods.

Lack of pieces which could be brought in connection with concrete inventory items, the study of $17^{\text {th }}$ century written sources was carried out parallel to the scientific investigation of samples stemming from Hungarian embroideries dated to the same period.

Hundreds of economic- and inventory-type documents, mentioning different kinds of threads in the same list, were taken into consideration to have a picture about the metal threads which could be seen with the naked eye and described by the compilers. The morphologically simplest ones, often in various names figure in the lists: flat metal strip, wire (often named scofium), their variants made by winding them around a fibrous core (filé threads), etc. Gold, silver, rarely gilt silver and copper (or copper alloy) are marked as metals they were fabricated from. For comparison, the investigation of around seventy samples taken from more than forty embroideries was carried out by optical- and scanning electron microscopy and energy dispersive X-ray microanalysis. Gold or gold alloys were not used for making strips and wires. All the gold-coloured ones but two were made of gilt silver. The exceptions were fabricated of brass, resp. silvered and gilt copper. Both types of silver-gilt file threads, known by now, figure among the samples: single- and double-sided gilt silver strips wound tightly or (in some cases, with the double-sided ones), sparsely around a silk yarn. The silver strips were also tightly or sparsely wound around the core. Not any filé thread of wire was among the threads. As a result, we got an approximate picture about the "palette of metal threads" of the period.

The pieces of data were compared with each other and with the analysis results of samples from European and Ottoman-Turkish weavings and embroideries, published in the special literature, as well as obtained by us. There were not any significant differences in morphology or material of the threads, apart from some small ones, hinting at their origin. We have not found any document by now, mentioning workshops or masters producing metal threads in the Hungarian territories of the given period.

Our hypothesis is that metal threads were scarcely fabricated in the territory of the Hungarian Kingdom or the Principality of Transylvania in the $17^{\text {th }}$ century. The silver-gilt file thread (with a thicker gold layer on the surface), the deep yellow colour of which reminded the compiler of the Hungarian, high standard gold coins, was called Hungarian gold or -gold thread. The good quality, not tarnished silver filé thread was probably described as Hungarian silver. The scofium, the name of the embroidery wires (gilt silver and silver ones), was neither a Hungarian nor a Turkish word. Since it was an Eastern import ware, probably the use of this term itself hinted at its Turkish origin. In some rare cases, the scofium and Turkish gold and silver figure together in the lists. We think that the latter ones describe filé threads of strip, flattened from silver or gilt silver wire, wound sparsely around a silk core. They were often used in the Ottoman Empire in the $17^{\text {th }}$ century, and the compilers could distinguish them from the other ones with the naked eye.

To support or reject this hypothesis, further research of written sources and scientific investigations are needed. 


\section{Irodalom}

BARABÁs 1881 Barabás Samu: Vásárlások Rákóczy György lakodalmához. Történelmi Tár 1881/1. 180-183.

BARAnYAI - Csernyánszky 1981 Baranyai Béláné - Csernyánszky Mária (gyűjt.): fasc. 86/35: Balpataki Jánosné árváinak javai, Nagyszeben, 1652. 144-146.; fasc. 89/13: Thököly leltár, Árva vára, 1670. 8-11. In: Urbaria et Conscriptiones 6. Művészettörténeti adatok. Az MTA Művészettörténeti Kutató Csoportjának forráskiadványai XVIII. Budapest, 1981.

BarAnYal - CSERnYÁnszky 1984 Baranyai Béláné - Csernyánszky Mária (gyűjt.): fasc. 102/30: „Inventarium bonum rerumque mobilium... Gregorii Gellii...capitanei campestri..." . 77-80.; fasc. 107/44: "Consignatio...universorum rerum mobilium... Comitis Nicolai Bercsény occasione occupationis arcis Unghvár ... inventarum..." 541-548.; fasc. 111/3: „....Nagyságos Alia Maria Kis Asszonynak hol mi javait...Feiervarott inventaltatta...” 148-149.; fasc. 118/2: Bethlen Gábor fejedelem palotájában lévő ingóságok összeírása, Gyulafehérvár, 1629. 128-148.; fasc. 118/5 „...Groff Barchay Judith Asszony... Murány Várában levő Portikai..." 304-311. In: Urbaria et Conscriptiones 7. Müvészettörténeti adatok. Az MTA Művészettörténeti Kutató Csoportjának forráskiadványai XIX. Budapest, 1984.

BARANYAI - CsernYÁnszky - BARACKA 1975 Baranyai Béláné - Csernyánszky Mária - Baraczka Istvánné (gyűjt.): fasc. 49/25: „Inventarium...bonum ad arcem Scepusiensem et dirutum castrum Richno pertinentium." 283-285. In: Urbaria et Conscriptiones 4. Müvészettörténeti adatok. Az MTA Művészettörténeti Kutató Csoportjának forráskiadványai XI. Budapest, 1975.

BÁRTFAI SzABó 1919 Bártfai Szabó László: Oklevéltár a gróf Csáky család történetéhez l. 2. rész: Oklevelek 1500-1818-ig. Budapest, 1919.

BekE - BarabÁs 1888 Beke Antal - Barabás Samu (közl.): I. Rákóczy György és a porta. Levelek és okiratok. Budapest, 1888.

BINET 1622 Binet, Étienne (René François írói álnéven): Essay des merveilles de nature et des plus nobles artifices. Rouen, 1622. https://gallica.bnf.fr/ark:/12148/bpt6k58099t.image (letöltés: 2018. augusztus 10.)

BIRINGuccio 1540 Biringuccio, Vanoccio: De la Pirotechnia. Venetia, 1540. https://library.si.edu/digital-library/book/ delapirotechnial00biri (letöltés: 2018. augusztus 10.)

BoIZARD 1692 Boizard, Jean: Traité des monnoyes, de leurs circonstances et dépendances. Paris, 1692. https://books.google.hu/b ooks?id=BXtRAAAAcAAJ\&pg=PT20\&hl=hu\&source=gbs_selected_pages\&cad=2\#v=onepage\&q\&f=false (letöltés: 2018. augusztus 10.)

BREPOHL 1987 Brepohl, Erhard: Theophilus Presbyter und die mittelalterliche Goldschmiedekunst. Wien-Köln-Graz, 1987.

BRüsszel Katalógus 2004 de Jonghe, Daniel - Maquoi, Marie-Christine - Vanden Berghe, Ina - van Raemdonck, M. -Vereecken, V. - Verhecken-Lammens, Ch. - Wouters, J.: The Ottoman silk textiles of the Royal Museum of Art and History in Brussels. Brussels, 2004.

Costa - De Reyer - Betbeder 2012 Costa, Virginia - De Reyer, Dominique - Betbeder, Maria: A note on the analysis of metal threads. Studies in Conservation 57/2. 112-115.

CSERnYÁnsZky 1990 Csernyánszky Mária (gyűjt.): fasc. 101/26: „Inventarium omniam mobilium....in arce Chyaktornyensi inventata...”. („két egymástól csak kissé, jobbára írásmódban eltérő példány”), 24-27. (rövidebb leltár) 28-35. (hosszabb leltár). In: Urbaria et Conscriptiones 8. Müvészettörténeti adatok. Az MTA Művészettörténeti Kutató Csoportjának forráskiadványai XX. Budapest, 1990.

DEÁK 1883 Deák Farkas: Gróf Csáky István országbíró útiköltségeinek és bevásárlásainak jegyzéke 1666-ból és 1675-ből. Történelmi Tár 1883/3. 584-594.

DöBRENTEI 1842 Döbrentei Gábor (közl.): Hathalmy Péter marhái jegyzéke (1563). In: Régi Magyar Nyelvemlékek III. 2. Buda, 1842. 48-49.

EnCYCLopéDIE VI. 1756 Diderot, Denis - D’Alembert, Jean le Rond: Encyclopédie ou dictionnaire raisonné des sciences, des arts et des métiers VI. Paris, 1756.

ERDÉlyI ORSZAGGYüLÉsı EmLÉKEK 1882 „Anno 1627. die 30. Aprilis Fejérvaratt tött limitatio az orszagnak generalis gyűlésében”, 378-418.; „1627. oct. 22. Ujabb limitatio”, 434-479. In: Szilágyi Sándor (szerk.): Erdélyi Országgyülési Emlékek 8. (16211629). Budapest, 1882.

Esterházy Gyüjteményı Szakkatalógus II. 2010 Pásztor Emese - Bardoly István (szerk.): Thesaurus Domus Esterhazyanae II. Az Esterházy-kincstár textiliái az Iparmüvészeti Múzeum gyüjteményében. Budapest, 2010.

EsteRHÁZY InVENTARIUM 1642 Inventarium Rerum Illustrissimae quondam Comitissae Elizabethae Thurzó, alias III(ustrissimi) quondam Domini Comitis Stephani Esterhazi relictae viduae, in arce Lansér. MNL, P 108. Az Esterházy család hercegi ágának levéltára. Rep. 12. Fasc. Q. Nr. 635. (Détshy Mihály olvasata)

EsTERHAZZ INVENTARIUM 1685M Esterházy Pál végrendelete mellékletének egykori variánsa. MNL, P 108. Az Esterházy család hercegi ágának levéltára, Rep. 8. Fasc. C. Nr. 48., Katona Imre (közli és bevezető): A fraknói kincstár 1685. évi leltára. Savaria - A Vas Megyei Múzeumok Értesítője 17-18. 461-502. (konvolutum) 
EsteRHÁZY INVENTARIUm 1693 Inventarium Thesauri in Arce Frakno existentis. MNL, P. 108. Az Esterházy család hercegi ágának levéltára. Rep. 8. Fasc. C. Nr. 37. (Détshy Mihály olvasata)

GeIJER 1951 Geijer, Agnes: Oriental Textiles in Sweden. Copenhagen, 1951.

GÉRESI 1887 Géresi Kálmán: A nagy-károlyi gróf Károlyi-család oklevéltára IV. Budapest, 1887.

GERVERS 1982 Gervers, Veronica: The Influence of Ottoman Turkish Textiles and Costume in Eastern Europe with particular reference to Hungary. History, Technology, and Art, Monograph 4. Toronto, 1940.

JAKAB 1875 Özvegy gróf Teleki Mihályné Görgény várában talált fellelhető javainak összeírása, 1704. In: Jakab Elek: Sándor Pál kapithia s az erdélyi fejedelemség utolsó évei II. Történelmi Tár 1875. 162-182.

JÁRó 2003 Járó, Márta: On the History of a 17 $7^{\text {th }}$ Century Nobleman's Dolman and Mantle, based on the Manufacturing Technique of the Ornamental Metal Threads. Ars Decorativa 22. 27-45.

JÁró 2004 Járó, Márta: Goldfäden in den sizilischen (nachmaligen) Krönungsgewändern der Könige und Kaiser des Heiligen Römisches Reiches und im sogenannten Häubchen König Stephans von Ungarn - Ergebnisse wissenschaftlicher Untersuchungen. In: Seipel, Wilfried (Hrsg.): Nobiles Officinae: die königlichen Hofwerkstätten zu Palermo zur Zeit der Normannen und Staufer im 12. und 13. Jahrhundert. Ausstellungskatalog. Wien, 2004. 311-318.

JÁRó 2009 Járó Márta: A „hamis vagy rosszféle paszamántok" és más, „,alábbvaló” textíliák fémfonalai. In: ISIS Erdélyi Magyar Restaurátor Füzetek 8/9. Székelyudvarhely, 2009. 25-43.

JÁró 2010a Járó, Márta: Spätmittelalterliche Handwerkstechnologie: Der Metallfaden im Wiener Gold-Seide-Stoff für Abū Sa'îd. In: Korn, Lorenz - Ritter, Markus (Hrsg.): Beiträge zur Islamischen Kunst und Archäologie, Vol. 2, Wiesbaden, 2010. 136-142.

JÁRó 2010b Járó Márta: Fémfonalak az Esterházy-gyűjtemény textíliáin. In: Pásztor Emese - Bardoly István (szerk.): Thesaurus Domus Esterhazyanae II. Az Esterházy-kincstár textíliái az Iparmüvészeti Múzeum gyűjteményében. Budapest, 2010. 56-66.

JÁRÓ - GONDÁR 1988 Járó Márta - Gondár Erzsébet: Mediaeval membrane threads used for weaving and embroidery. In: Járó, Márta - Költő, László (eds.) Archaeometrical research in Hungary. Budapest, 1988. 255-266.

Járó - Tóth 1994 Járó Márta - Tóth Attila: Mode de fabrication des fils métalliques provenant des fouilles en Hongrie. In: Stefanaggi, Marcel (ed.): La conservation des textiles anciens. Volume des contributions des Journées d'Études de la SFIIC. Angers, 1994. 157-167.

JÁRÓ - Tо́тH 2013 Járó Márta - Tóth Attila: A „nyugati- és keleti-típusú" arany- és ezüstfonalak. A két fonaltípus „találkozása” egy soproni sírlelet textíliáin. Mütárgyvédelem 2011/36. 29-56.

KEMÉNY 1889 Kemény Lajos ifj. (közl.): Buda város árszabása II. Lajos korában, 1522. Történelmi Tár 1889/2. $372-384$.

KомÁRoмy 1885 Komáromy András (közl.): Kassa város levéltárából: Vér György ingóságai leltára, 1697. Történelmi Tár 1885/2. 401-409.

KомÁROмy 1886 Komáromy András: A tolcsvai Bónis-család levéltárából. Első közlemény, Bónis Ferenc inventáriuma kassai házának ingóságairól, 1661. Történelmi Tár 1886/1. 150-181.

КомÁROмy 1891 Komáromy András (közl.): Gróf Eszterházy Anna Julianna menyasszonyi hozománya 1644-ben. Történelmi Tár 1891/4. 683-688.

KомÁRomy 1896 Komáromy András: A báró Perényi család levéltárából. Negyedik közlemény (Perényi Mária gróf Csáky Istvánné nászhozománya, 437-444.) Történelmi Tár 1896/3.436-457.

KovÁcs S. 2010 Kovács S. Tibor: Huszárfegyverek a 15-17. században. Budapest, 2010.

KRÜNITZ IX, 1776 Krünitz, Johann Georg: Ökonomische Encyklopädie... Band 9. 1776.

KRÜNITZ XIX, 1788 Krünitz, Johann Georg: Ökonomische Encyklopädie... Band 19. 1788.

LÁszló 2001 László Emőke: Magyar reneszánsz és barokk hímzések. Az Iparmüvészeti Múzeum gyüjteményei II. Budapest, 2001.

LewIs 1763 Lewis, William:Commercium Philosophico-Technicum; or, the Philosophical Commerce of Arts:Designed as an attempt to improve Arts, Trades, and Manufactures. London, 1763. http://echo.mpiwg-berlin.mpg.de/MPIWG:2MARMQ1S (letöltés: 2018. augusztus 10.)

LUKINICH 1908 Lukinich Imre (közl.): Bethlen Farkasné Ostrosics Borbála ingóságainak leltára. Történelmi Tár 1908/1. 12-24.

PalotaY 1940 Palotay Gertrúd: Oszmán-török elemek a magyar hímzésben. Bibliotheca Humanitatis Historica 2. Budapest, 1940.

PAP 2000 Pap Ferenc: Kolozsvári harmincadjegyzékek (1599-1637). Bukarest-Kolozsvár, 2000.

PÁszToR 1997 Pásztor Emese: „Tafota melyre az virágokat írták” Ars Decorativa 16. 35-47. 
PÁsztor 2010 Pásztor Emese: Oszmán-török textilemlékek a fraknói Esterházy-kincstár gyűjteményében. In: Pásztor Emese - Bardoly István (szerk.): Thesaurus Domus Esterhazyanae II. Az Esterházy-kincstár textíliái az Iparmüvészeti Múzeum gyüjteményében. Budapest, 2010. 36-55.

RAdVÁnszky I. 1896 Radvánszky Béla: Magyar családélet és háztartás a XVI. és XVII. században I. Budapest, 1896.

RAdVÁNSZkY II. 1879 Radvánszky Béla: Magyar családélet és háztartás a XVI. és XVII. században II. (Az adatgyűjtemény I. kötete). Budapest, 1879.

RAdVÁnszky III. 1879 Radvánszky Béla: Magyar családélet és háztartás a XVI. és XVII. században II. (Az adatgyűjtemény II. kötete). Budapest, 1879.

RADVÁNSZky 1888 Radvánszky Béla: Udvartartás és számadáskönyvek I. Budapest, 1888.

SzABó 1878 Szabó Károly: Haller János följegyzései 1685-1687. Történelmi Tár 1878/3.679-690.

RinuY 1995 Rinuy, Anne: Fils d'or et d'argent des broderies ottomanes: identification de leur mode de fabrication. In: Martiniani-Reber, Marielle: Çeyiz, broderies de l'Empire Ottoman. Genève, 1995. 13-26.

SzERÉmI 1880 Szerémi (közl.): Gróf Illésházy llona menyasszonyi hozománya. Történelmi Tár 1880/1. 195-201.

SZILAGYI 1887 Szilágyi Sándor: Okiratok a két Rákóczy György történetéhez. I. Rákóczy György leszámolása Brandenburgi Katalinnal. Történelmi Tár 1887/2. 209-242.

TAKÁCs 1986 Takács Vilmos (fordította, jegyzetekkel ellátta és a bevezetőt írta): Theophilus Presbyter: A különféle müvességekről. Budapest, 1986.

THALY 1873 Thaly Kálmán: Késmárki Thököly Imre naplói, leveleskönyve és egyéb emlékezetes írásai ll. (ebben:„Munkácsvárában Thököly uram házassága előtt letett ládáimban illyen jók voltanak”, 1684 k. 686-688.; „Barkóczy Örzsébet ládáiban való jóknak lajstroma", 1684. 688-701.). Monumenta Hungariae Historica 24. Scriptores. Budapest, 1873.

THALY 1879 Thaly Kálmán: A régi magyar hímző-művészetről 1707-1708. Archaeologiai Értesítő XIII. 344-350.

THALY 1883a Thaly Kálmán: A hazai képzőművészet, műipar, nemzeti viselet, fegyvergyártás és háztartás történetéhez II. Rákóczi Ferencz udvarában s korában (1706-1711). Harmadik közlemény. Történelmi Tár 1883/1. 184-198.

THALY 1883b Thaly Kálmán: A hazai képzőművészet, műipar, nemzeti viselet, fegyvergyártás és háztartás történetéhez II. Rákóczi Ferencz udvarában s korában (1706-1711). Negyedik és befejező közlemény. Történelmi Tár 1883/2. 375-406.

THALY 1900 Thaly Kálmán: Munkácsi leltárak s udvartartási iratok (1680-1701). Történelmi Tár Új Folyam 1. $321-384$.

V. EMBER 1980 V. Ember Mária: Régi textíliák. Budapest, 1980.

VINCZE 1878 Vincze Gábor (közl.): I. Rákóczi György fejedelem kincseinek összeírása. Történelmi Tár 1878/4. 940-949.

WeiszbuRG et Al. 2017 Weiszburg, Tamás G. - Gherdán, Katalin - Ratter, Kitti - Zajzon, Norbert - Bendő, Zsolt - Radnóczi, György - Takács, Ágnes - Váczi, Tamás - Varga, Gábor - Szakmány, György: Medieval Gilding Technology of Historical Metal Threads Revealed by Electron Optical and Micro-Raman Spectroscopic Study of Focused lon Beam-Milled Cross Sections. Analytical Chemistry 89. 10753-10760. 
